\title{
The role of tumor microenvironment in resistance to anti-
}

\section{angiogenic therapy [version 1; peer review: 2 approved]}

\author{
Shaolin Ma(iD1,2, Sunila Pradeep1, Wei Hu11, Dikai Zhang2, Robert Coleman1, \\ Anil Sood (D) 1,3,4
}

\footnotetext{
${ }^{1}$ Department of Gynecologic Oncology and Reproductive Medicine, The University of Texas MD Anderson Cancer Center, Houston, TX, USA

${ }^{2}$ Reproductive Medicine Research Center, Department of Gynecology and Obstetrics, The Sixth Affiliated Hospital, Sun Yat-sen University, Guangzhou, Guangdong province, China

${ }^{3}$ Department of Cancer Biology, The University of Texas MD Anderson Cancer Center, Houston, TX, USA

${ }^{4}$ Center for RNA Interference and Non-Coding RNA, The University of Texas MD Anderson Cancer Center, Houston, TX, USA
}

V1 First published: 15 Mar 2018, 7(F1000 Faculty Rev):326

https://doi.org/10.12688/f1000research.11771.1

Latest published: 15 Mar 2018, 7(F1000 Faculty Rev):326

https://doi.org/10.12688/f1000research.11771.1

\section{Abstract}

Anti-angiogenic therapy has been demonstrated to increase progression-free survival in patients with many different solid cancers. Unfortunately, the benefit in overall survival is modest and the rapid emergence of drug resistance is a significant clinical problem. Over the last decade, several mechanisms have been identified to decipher the emergence of resistance. There is a multitude of changes within the tumor microenvironment (TME) in response to anti-angiogenic therapy that offers new therapeutic opportunities. In this review, we compile results from contemporary studies related to adaptive changes in the TME in the development of resistance to antiangiogenic therapy. These include preclinical models of emerging resistance, dynamic changes in hypoxia signaling and stromal cells during treatment, and novel strategies to overcome resistance by targeting the TME.

\section{Keywords}

tumor microenvironment, anti-angiogenic therapy, drug resistance, MET signaling

\section{Open Peer Review}

Approval Status

1

2

version 1

15 Mar 2018

Faculty Reviews are review articles written by the prestigious Members of Faculty Opinions. The articles are commissioned and peer reviewed before publication to ensure that the final, published version is comprehensive and accessible. The reviewers who approved the final version are listed with their names and affiliations.

\section{Miguel Quintela-Fandino, CNIO-Spanish National Research Cancer Centre, Madrid, Spain}

2. Andrew Reynolds, The Breast Cancer Now

Toby Robins Research Centre, The Institute of Cancer Research, London, UK

Any comments on the article can be found at the end of the article. 
Corresponding author: Anil Sood (asood@mdanderson.org)

Author roles: Ma S: Conceptualization, Writing - Original Draft Preparation, Writing - Review \& Editing; Pradeep S: Writing - Review \& Editing; Hu W: Writing - Review \& Editing; Zhang D: Writing - Review \& Editing; Coleman R: Supervision, Writing - Review \& Editing; Sood A: Conceptualization, Supervision, Writing - Review \& Editing

Competing interests: $\mathrm{RLC}$ has received grant funding from Genentech, Merck, Janssen, Clovis, AZ, and Abbvie and serves on the scientific steering committee as an investigator for Tesaro, Clovis, AZ, and Abbvie. AKS serves on the advisory board for Kiyatec and has received research funding from $M$-Trap. The other authors declare that they have no competing interests.

Grant information: Portions of this work were supported by the National Institutes of Health (P50 CA217685, P50 CA098258, CA177909, and R35 CA209904), the Frank McGraw Memorial Chair in Cancer Research, the Ann Rife Cox Chair in Gynecology, the American Cancer Society Research Professor Award, and the Institutional Core Grant (CA16672) to the MD Anderson Cancer Center from the National Institutes of Health.

The funders had no role in study design, data collection and analysis, decision to publish, or preparation of the manuscript.

Copyright: (c) $2018 \mathrm{Ma}$ S et al. This is an open access article distributed under the terms of the Creative Commons Attribution License, which permits unrestricted use, distribution, and reproduction in any medium, provided the original work is properly cited.

How to cite this article: Ma S, Pradeep S, Hu W et al. The role of tumor microenvironment in resistance to anti-angiogenic therapy [version 1; peer review: 2 approved] F1000Research 2018, 7(F1000 Faculty Rev):326 https://doi.org/10.12688/f1000research.11771.1

First published: 15 Mar 2018, 7(F1000 Faculty Rev):326 https://doi.org/10.12688/f1000research.11771.1 


\section{Introduction}

Angiogenesis is well recognized as an important step in the growth and progression of many tumor types ${ }^{1}$. Over the last 15 years, anti-angiogenic therapy has become an effective modality for cancer therapy. Several vascular endothelial growth factor/receptor (VEGF/R) inhibitors have been approved by the US Food and Drug Administration for various solid tumors, including metastatic colorectal cancer (mCRC), metastatic renal cell cancer, metastatic gastric cancer, non-small-cell lung cancer, recurrent/metastatic cervical cancer, recurrent ovarian cancer, and glioblastoma multiforme (GBM). Although improvements in objective response and progression-free survival (PFS) have been seen, the impact of anti-angiogenic therapy on patient overall survival (OS) is limited (Table 1) because of a host of factors, including the induction of resistance ${ }^{2}$. The modes of resistance to angiogenesis inhibitors, mechanisms of acquired or intrinsic resistance, and strategies for overcoming resistance have been discussed (see 3-5). Meanwhile, new mechanisms and therapies for anti-angiogenic resistance have emerged over the last 3-5 years. Evidence suggests that changes in the tumor microenvironment (TME) play a critical role in such adaptation ${ }^{6}$. This review focuses mainly on the role of the TME in response and resistance to anti-angiogenic therapy (Figure 1), and novel strategies to overcome resistance by targeting the TME are also discussed.

\section{The role of hypoxia in resistance to anti-angiogenic therapy}

Previous studies have shown that resistance to anti-angiogenic therapy is associated with hypoxia-induced alterations, VEGFindependent cytokine-driven endothelial growth, mobilization of bone marrow-derived pro-angiogenic hematopoietic cells or endothelial progenitors, and vessel co-option ${ }^{2-5,7}$. Anti-angiogenic therapy inhibits tumor growth effectively by reducing vessel density; however, the subsequent expression of hypoxia-inducible factors (HIFs) and the responsive genes (for example, $V E G F$, $V E G F R$, carbonic anhydrase $[C A] I X$, and CAXII) can lead to therapeutic resistance ${ }^{8}$. In recent years, there has been growing evidence that hypoxia-triggered overexpression of HIF subunits and the activated downstream pathways play a critical role in resistance to anti-angiogenic therapy.

\section{Role of HIF-1 $\alpha$ in anti-angiogenic therapy}

There are three $\alpha$ subunits (HIF- $1 \alpha,-2 \alpha$, and $-3 \alpha$ ) and one $\beta$ subunit in the HIF family. HIF- $1 \alpha$ is the oxygen-regulated subunit that has been studied in inflammation, diabetes, cardiovascular disease, and cancer. In the presence of $\mathrm{O}_{2}$, prolyl hydroxylase domain (PHD) proteins (principally PHD2) can use $\mathrm{O}_{2}$ and a-ketoglutarate to subject HIF-1 $\alpha$ to prolyl hydroxylation on proline residue 402/5649. Von Hippel-Lindau protein recruits ubiquitin ligase complex by interacting with Elogin $\mathrm{C}$ after HIF-1 $\alpha$ prolyl hydroxylation. Then, ubiquitinated HIF- $1 \alpha$ can be recognized and degraded by the proteasome. Meanwhile, factor inhibiting 1 (FIH-1), which is an asparaginyl hydroxylase, can block HIF-1 $\alpha$ transcription by blocking the interaction of HIF-1 $\alpha$ transactivation domain with its co-activators $\mathrm{p} 300$ and $\mathrm{CBP}^{9}$. When $\mathrm{O}_{2}$ is deprived, the inhibition of prolyl hydroxylase (for example, PHD2) and asparaginyl hydroxylase activity (for example, FIH-1) increases the stability and transcription of HIF- $1 \alpha$ and consequently causes the dimerization of HIF- $1 \alpha$ and HIF- $1 \beta$ to form HIF1. HIF1 can bind to target genes and increase gene transcription?

HIF- $1 \alpha$ is a potent pro-angiogenic factor that has been associated with the regulation of VEGF, stromal cell-derived factor 1 (SDF1), plasminogen activator inhibitor 1 (PAI1), angiopoietins (Ang-1 and -2), platelet-derived growth factor (PDGF), Tie2 receptor, and matrix metalloproteinases (MMP-2 and -9) ${ }^{10,11}$. The expression of HIF- $1 \alpha$ is driven by hypoxia and mediated by histone deacetylase (HDAC). Deacetylation by HDAC is a critical post-translational modification to HIF- $1 \alpha$ signaling. Upregulation of HDACs has been observed in response to increasing HIF- $1 \alpha$ signaling under hypoxia ${ }^{12}$. A phase I clinical trial showed that the addition of HDAC inhibitor abexinostat to pazopanib led to a durable response in some patients who experienced progression during anti-VEGF therapy ${ }^{13}$. In addition, inhibiting HDACs can abrogate the expression of HIF- $1 \alpha$ protein in hypoxic conditions and there is an additive or synergistic effect between HDAC and VEGFR inhibitors in resistant cancers ${ }^{12,14}$. In vitro and in vivo data have demonstrated that nucleus accumbensassociated protein-1 (NAC1), a critical molecule in promoting glycolysis under hypoxia, mediates glycolysis via HDAC4mediated stabilization of HIF-1 $\alpha$. The knockdown of NAC1 exhibits anti-tumor effects of bevacizumab, which means that NAC1 may be involved in resistance to anti-angiogenic therapy ${ }^{15}$. Thus, NAC1-HDAC4-HIF-1 $\alpha$ signaling might be an important pathway in regulating resistance under hypoxia.

\section{MET signaling}

HIF- $1 \alpha$ can also regulate the c-MET/HGF pathway, which can induce tumor angiogenesis through stimulation of endothelial cell (EC) proliferation, migration, and tubulogenesis ${ }^{16}$. Hypoxia enhances c-MET/HGF signaling by activating HIF- $1 \alpha$ in several types of cancers such as lung, ovarian, and cervical cancers ${ }^{17}$. MET and VEGFR pathways share common downstream molecules such as mitogen-activated protein kinase (MAPK), ERK, AKT, and focal adhesion kinase (FAK), and the activation of c-MET/HGF might lead to the activation of VEGFR signaling. It has been shown that MET enhances the expression of VEGFA by interacting with src homology 2 domain containing and suppressing angiogenesis suppressor thrombospondin $1^{18}$. Other studies have also demonstrated that MET contributes to resistance to $\operatorname{VEGF}(\mathrm{R})$ inhibitors via the activation of ERK-MAPK and PI3K-AKT signaling ${ }^{19}$. To identify mediators of resistance to anti-angiogenic therapy, Jahangiri et al..$^{20}$ generated a novel glioma cell-derived bevacizumab-resistant xenograft model by injecting cells subcutaneously and harvesting the least responsive xenograft tumor cells and implanting them into mice with longterm treatment of bevacizumab $(10 \mathrm{mg} / \mathrm{kg})$. After the tumors were serially passaged subcutaneously (three cycles) in vivo, a stably resistant xenograft model was developed ${ }^{20}$. Microarray analysis of this model showed upregulation of c-Met; adding a MET inhibitor with bevacizumab treatment impeded tumor invasion and prolonged survival in resistant mice ${ }^{20}$. Cabozantinib, a multitargeting inhibitor of MET, VEGFR2, AXL, and RET, can overcome HGF/MET signaling-mediated resistance to panVEGFR inhibition in neuroblastoma mouse models ${ }^{21}$. Furthermore, 


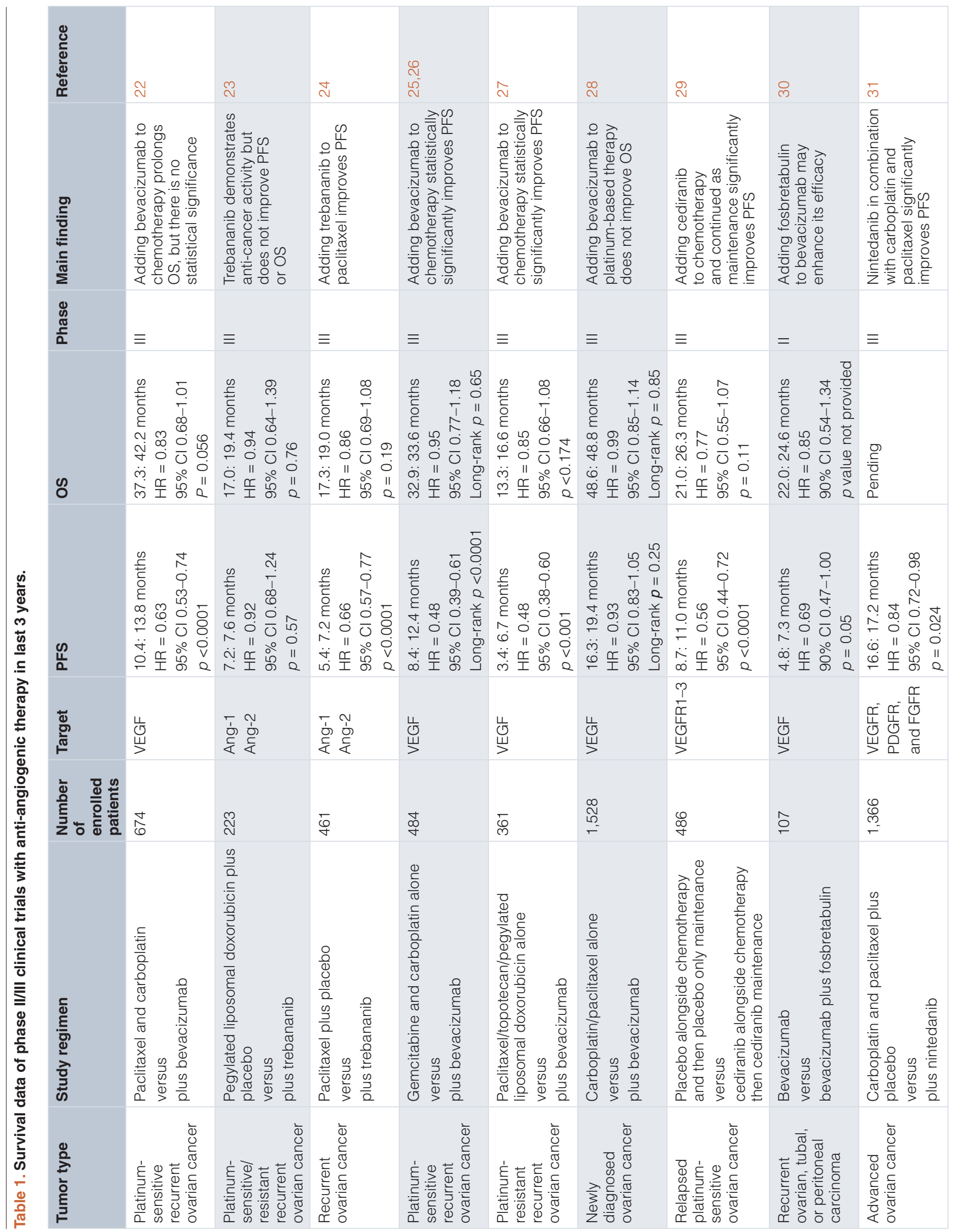




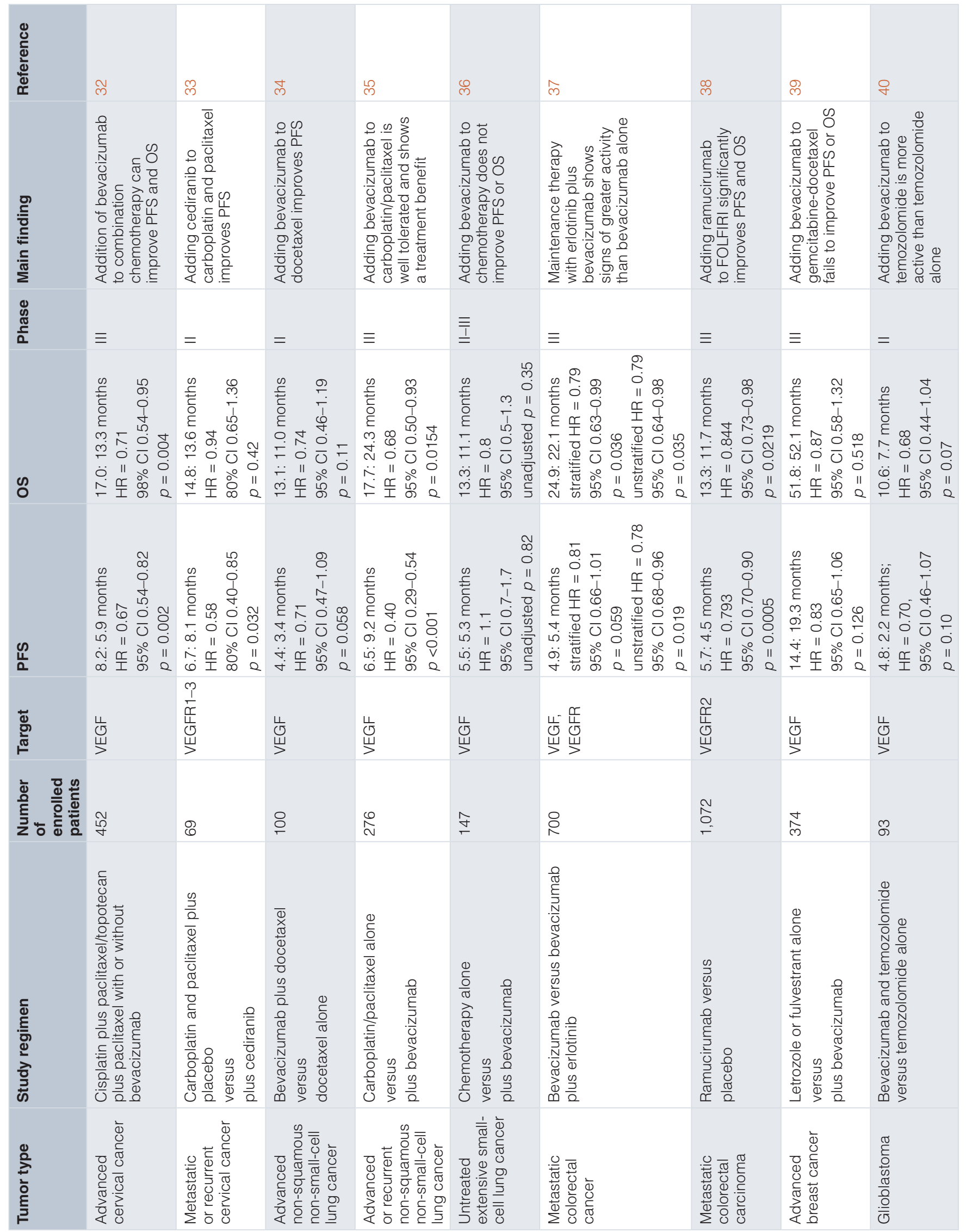




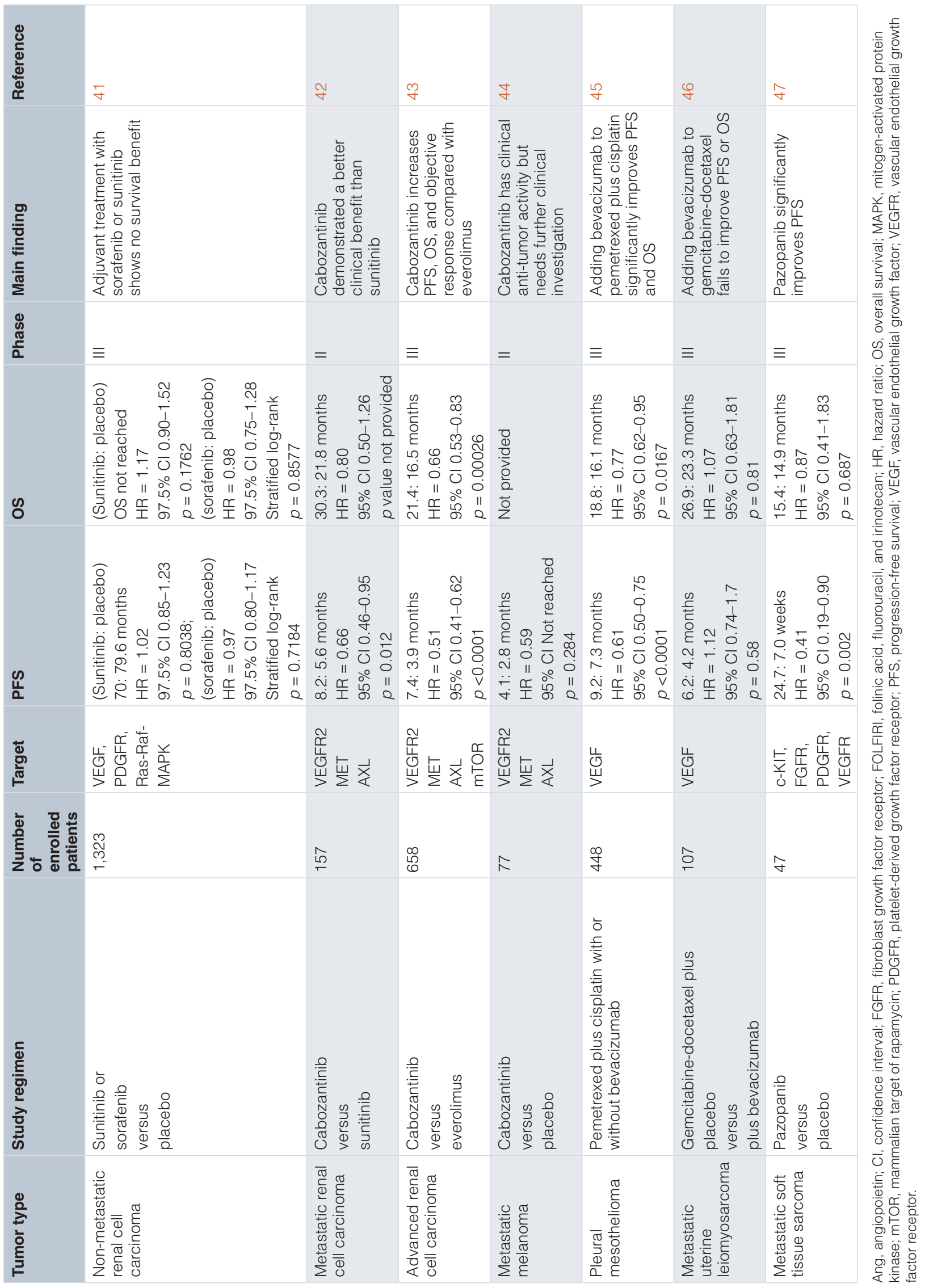




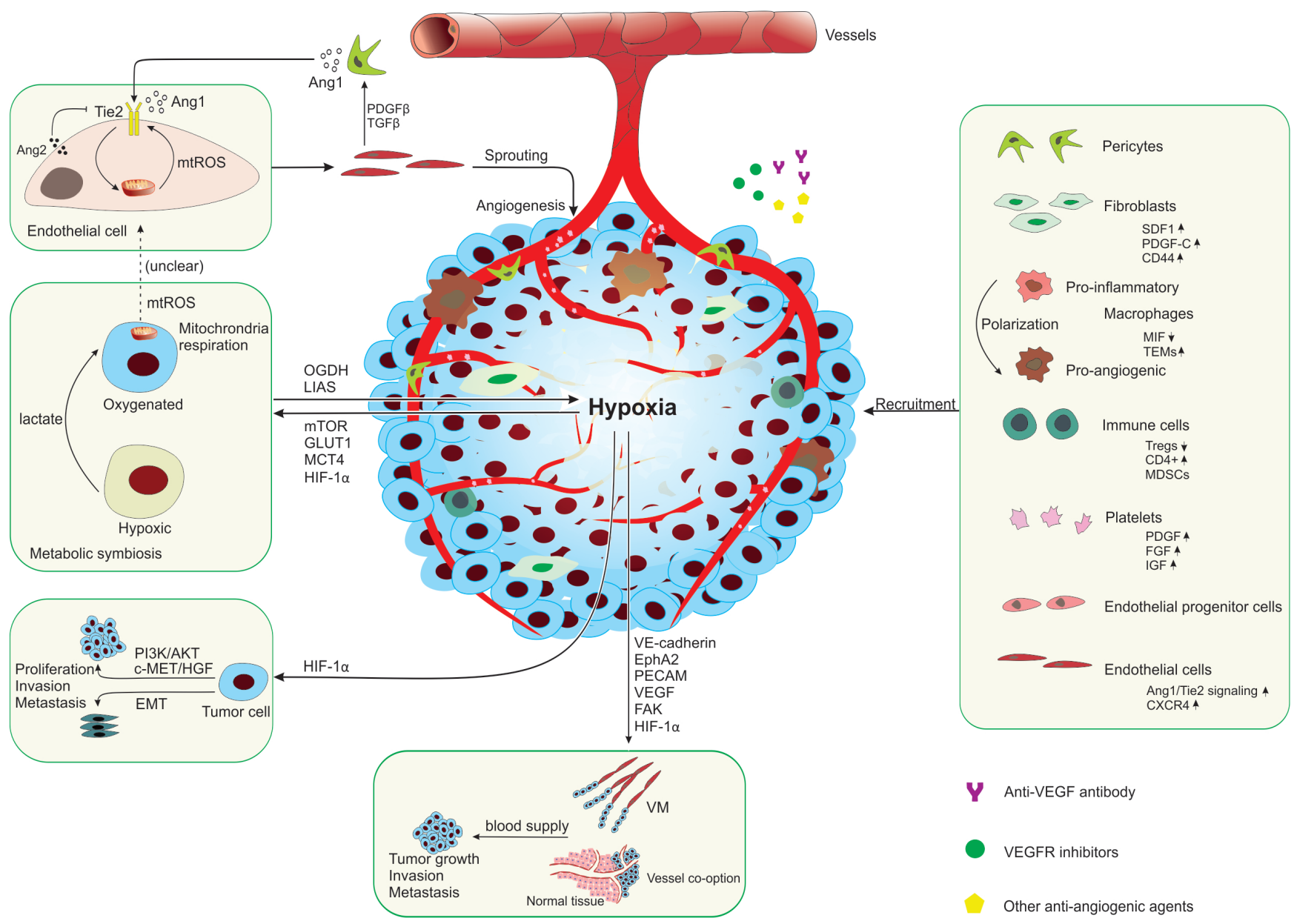

Figure 1. Schematic illustration of the role of the tumor microenvironment in resistance to anti-angiogenic therapy. Anti-angiogenic therapy inhibits tumor growth by reducing vessel density; however, the subsequent hypoxia and the responsive genes can cause resistance to such therapy. The hypoxia-related metabolic symbiosis, invasion and metastasis, vessel co-option, and vasculogenic mimicry (VM) lead to resistance to anti-angiogenic therapy. The recruitment of stromal cells also plays a critical role in resistance to anti-angiogenic therapy. Ang1/2, angiopoietin 1/2; CXCR4, C-X-C chemokine receptor type 4; EMT, epithelial-to-mesenchymal transition; EphA2, Eph receptor A2; FAK, focal adhesion kinase; FGF, fibroblast growth factor; GLUT1, glucose transporter-1; HGF, hepatocyte growth factor; HIF-1 $\alpha$, hypoxiainducible factor $1 \alpha$; IGF, insulin-like growth factor; LIAS, lipoic acid synthase; MCT4, monocarboxylate transporter 4; MDSC, myeloid-derived suppressor cell; MIF, macrophage migration inhibitory factor; mTOR, mammalian target of rapamycin; mtROS, mitochondria reactive oxygen species; OGDH, oxoglutarate dehydrogenase; PDGF, platelet-derived growth factor; PECAM, platelet endothelial cell adhesion molecule; SDF1, stromal cell-derived factor 1; TEM; Ties-expressing macrophage; Treg, regulatory T cell; VE-cadherin, vascular endothelial cadherin; VEGF, vascular endothelial growth factor.

c-MET can form a complex with $\beta 1$-integrin extensively in bevacizumab-resistant GBM and result in increased migration ${ }^{48}$. It has been demonstrated in some preclinical studies that increased invasiveness and metastasis is caused by c-MET activation due to the inhibition of VEGF signaling, which also results in resistance to anti-angiogenic therapy.

c-MET/HGF signaling leads to the activation of numerous signaling cascades, especially those related to epithelial-tomesenchymal transition (EMT). Anti-angiogenic treatment can activate the EMT repressor ZEB2 by upregulating HIF-1 $\alpha$. ZEB2 can downregulate ephrinB2 through promoter binding to enhance tumor invasiveness ${ }^{49}$. The development of EMT has been confirmed in a multi-generational glioblastoma xenograft model, which is established by selecting the fastest growing tumor during bevacizumab treatment in each generation and reimplanting them into new mice. The authors observed that critical EMT transcription factors SNAI2 and ZEB2 were upregulated during bevacizumab treatment ${ }^{50}$. A recent study showed a synergistic effect of c-MET and VEGFR inhibitor (sunitinib) in reducing invasiveness and metastasis of RIP-Tag2 and Panc-1 tumors $^{51}$. Similarly, another study demonstrated that VEGF could directly and negatively regulate GBM invasion by inhibiting MET activation, which is dependent on VEGFR2 ${ }^{52}$. Consequently, the broad use of anti-angiogenic therapy could restore and increase MET levels and induce EMT, which is 
confirmed in GBM patients who are resistant to bevacizumab ${ }^{52}$. Overall, these data suggest that HGF/MET signaling plays a crucial role in increased invasiveness, metastasis, and drug resistance during anti-angiogenic therapy. The phase III METEOR trial demonstrated that cabozantinib (MET, VEGFR, and AXL inhibitor) treatment resulted in improvements in PFS, OS, and objective response rate in patients with advanced renal cell cancer and bone metastases after previous VEGFR inhibition therapy $^{53}$. Similarly, a phase II study showed that the dual MET/ VEGFR2 inhibitor foretinib had anti-tumor activity in patients with papillary renal carcinoma and a high response rate in patients with germline $M E T$ mutations $^{54}$. These studies suggest a promising future for combining MET and VEGF/R inhibitors to overcome drug resistance.

\section{Vascular mimicry}

Tumor cells have a complex vasculature system that can develop compensatory mechanisms to evade therapeutic effect, such as revascularization. Vasculogenic mimicry (VM) is a blood supply system whereby vascular-like channels may form independently of $\mathrm{ECs}^{55}$. VM is regulated by various molecules, including vascular endothelial cadherin (VE-cadherin), ephrin type-A receptor 2 (EphA2), platelet EC adhesion molecule (PECAM), VEGF, and FAK ${ }^{56}$. In addition, hypoxia-related pathways, especially HIF- $1 \alpha$, are important regulatory mechanisms in the process of $\mathrm{VM}^{57}$. Growing evidence indicates that tumor cells are capable of mimicking EC characteristics to form VM. It is reported that the VEGFR2 inhibitor sunitinib can increase VM under hypoxia by transforming tumor cells into endothelial-like cells ${ }^{58}$. Another study showed that PECAM1 (also known as CD31, a mediator of angiogenesis that regulates EC-cell interactions) positive melanoma cells have the ability to form tube-like structures in vitro and could incorporate with vascular lumens in vivo ${ }^{59,60}$. It was also confirmed that PECAM1 ${ }^{+}$ melanoma cells are enriched and might lead to resistance during anti-VEGF therapy ${ }^{60}$. Similarly, in a breast cancer mouse model, VM channels were increased after treatment with sunitinib and related to increased hypoxia. However, this vessel regrowth exists only in the models bearing cells with the ability to form $\mathrm{VM}^{61}$. Those findings showed that the process of VM depends mainly on specific tumor cell characteristics that can resemble EC features. Anti-angiogenic therapy-induced VM is highly related to hypoxia and leads to angiogenic rebound by forming endothelium-independent vascular channels.

\section{Blood vessel co-option}

In addition to VM, cancer cells can develop another vascular network for the resupply of oxygen and nutrients to escape anti-angiogenic therapy by blood vessel co-option ${ }^{62}$. Vessel co-option is a process whereby cancer cells "hijack" pre-existing vasculature and migrate along the vessels of host organs to gain a blood supply ${ }^{63}$. It has been shown that vessel co-option occurs mainly in well-vascularized organs such as the brain, lungs, and liver in both human cancers and animal models of cancer ${ }^{63,64}$. A more recent study revealed that vessel co-option also occurs in lymph node metastases where it supports the growth of lymph node metastatic lesions. Furthermore, clinical evidence suggests that anti-angiogenic therapy (for example, bevacizumab) may not reduce vessel density in lymph node metastases from patients who received bevacizumab treatment ${ }^{65}$. Other studies in preclinical models of glioblastoma and melanoma brain metastases have shown that tumor progression during treatment with anti-angiogenic drugs is associated with the induction of vessel co-option, which results in therapy resistance ${ }^{66,67}$. In human lung metastases from breast, colorectal, or renal cancer, vessel co-option appears to be common, and in preclinical models of lung metastasis, vessel co-option was shown to be associated with resistance to sunitinib. The predominant mechanism of vessel co-option in metastatic tumors in the lungs is a process whereby cancer cells invade alveolar spaces and co-opt alveolar walls and their constituent alveolar capillaries. Subsequently, pneumocytes are lost from these co-opted alveolar walls, leaving behind the co-opted alveolar capillaries $^{68,69}$. Another preclinical study revealed that the VEGFR inhibitor sorafenib induces vessel co-option in an orthotopic model of hepatocellular carcinoma (HCC) and that this increase in vessel co-option was associated with resistance to sorafenib ${ }^{70}$. Several pro-EMT transcription factors (for example, vimentin, ZEB1, and ZEB2) were upregulated significantly in the sorafenib-resistant tumors, which suggested a link between EMT and vessel co-option ${ }^{70}$. Also, CD34 $4^{+}$microvessels and $\alpha$-smooth muscle actin $(\alpha \mathrm{SMA})^{+}$pericytes were depleted in both sorafenib -sensitive and -resistant tumor tissues compared with tissues without treatment, which indicates that the acquired resistance was not induced by the re-induction of angiogenesis ${ }^{70}$. Importantly, other studies have also demonstrated that antiangiogenic therapy can promote cancer cell invasion and induce an EMT switch, which is linked to acquired resistance ${ }^{71,72}$. However, the molecular pathways involved in the induction of vessel co-option during anti-angiogenic therapy remain unclear. In addition, one study has shown that $\mathrm{mCRC}$ with histopathological features of co-opted vessels is associated with worse response to bevacizumab than patients with angiogenic metastases ${ }^{73}$. However, further studies using patient samples obtained after treatment with anti-angiogenic therapy are needed to fully clarify the clinical association between vessel co-option and resistance to anti-angiogenic therapy.

\section{Metabolic symbiosis}

Another compensatory mechanism to hypoxia is metabolic symbiosis, a process in which tumor cells in the oxygenated region can use lactate from hypoxic, glycolytic tumor cells to produce ATP $^{74}$. This metabolic shift is driven by HIF- $1 \alpha$ and is associated with the activation of glycolytic genes ${ }^{75}$. Pisarsky et al. $^{76}$ established a mouse orthotopic model with a stable murine breast cancer cell line (Py2T) and developed an evasive resistance model with long-term treatment with nintedanib (potent inhibitor of fibroblast growth factor [FGF] receptor 1 [FGFR1], 2, and 3, PDGF receptor $\alpha / \beta$, and VEGFR1, 2, and $3)$. In this model, evasive resistance was found to be associated with the establishment of metabolic symbiosis but not tumor revascularization ${ }^{74,76}$. Allen et al. observed similar metabolic symbiosis with anti-angiogenic therapy in the RIP1-Tag2 transgenic mouse pancreatic neuroendocrine tumor (PanNET) model $^{77}$. Upregulation of glucose transporter 1 (GLUT1) and monocarboxylate transporter 4 (MCT4) in the hypoxic regions can be 
abrogated by knocking out HIF-1 $\alpha^{77}$. Furthermore, the mammalian target of rapamycin (mTOR) signaling pathway is involved in metabolic symbiosis during anti-angiogenic therapy, and the addition of rapamycin, an inhibitor of mTOR, can block this metabolism shift ${ }^{77}$. Another study in a renal cell carcinoma patient-derived xenograft model showed that the metabolic symbiosis phenotype is involved in anti-angiogenic resistance and can be halted by blocking mTOR signaling ${ }^{78}$. Inhibition of the upstream AKT/mTOR pathway can also sensitize renal cancer cells to multi-kinase inhibitor regorafenib ${ }^{79}$.

Mitochondria contribute to the major part of oxygen consumption and have been found to influence cell signaling by producing reactive oxygen species (ROS) and metabolites ${ }^{80}$. Tie-2 receptors and one of the ligands, Ang-1, are related to the activation of ROS and angiogenic response. Mitochondrial ROS can be triggered by Ang1/Tie2 signaling, and the released ROS can mediate the Ang1/Tie2 pathway and pro-angiogenic response $^{81}$. In breast and lung cancer models, a multi-kinase inhibitor could induce hypoxia-mediated tumor glycolysis and switch it to long-term reliance on mitochondrial respiration ${ }^{82}$. Mutation in two mitochondrial genes-oxoglutarate dehydrogenase $(O G D H)$ and lipoic acid synthase (LIAS) — can stabilize HIF- $1 \alpha$ in a non-hydroxylated form, and the depletion of OGDH or LIAS leads to increased HIF- $1 \alpha^{83}$. The induction of metabolic symbiosis in response to anti-angiogenic therapy enables tumor cells to circumvent the anti-tumor effects of therapeutic agents by using cell survival pathways. It is clear that mitochondria, as the primary energy factory, are highly involved in hypoxia responses and help tumor cells survive anti-angiogenic therapy.

\section{Invasion and metastasis}

Many studies have shown that anti-angiogenic therapy promotes tumor invasion and metastasis, which might be triggered by an anti-angiogenic therapy-associated increase in tumor hypoxia $^{49,51,52,71,84}$. The transcription of HIF-regulated genes is in control of diverse steps of tumor invasion and metastasis, including EMT, activation of MET signaling, recruitment of stromal cells, VM, and vessel co-option. It is reported that a triple-negative breast cancer mouse model exhibits increased MMP2 levels after discontinuation of sunitinib and VM channels were also observed accompanied by reduced endotheliumdependent vessel development ${ }^{61}$. Data from patient samples revealed that the development of VM has a positive correlation with high expression of HIF-1 $\alpha$, MMP2, VE-cadherin, and $\mathrm{CD} 31^{61}$. In breast cancer, right open reading frame (RIO) kinase 3 , a conserved protein of atypical serine/threonine protein kinases, is involved in promoting hypoxia-induced invasion and metastasis via maintaining actin cytoskeletal organization ${ }^{85}$. Hypoxia induces circadian clock gene period 2 (PER2) degradation and enhances invasion and activation of EMT genes (TWIST1, SLUG, and SNAIL) in breast cancer ${ }^{86}$. Two independent signaling loops have been clarified to be involved in hypoxiastimulated breast cancer invasion and metastasis: (i) in C-X-C chemokine ligand 16 (CXCL16) signaling, cancer cells secrete CXCL16, which binds to C-X-C chemokine receptor type 6 (CXCR6) on mesenchymal stem cells (MSCs), and in turn MSCs secrete CXCL10, which binds to CXCR3 on cancer cells, and (ii) MSCs secrete chemokine ligand 5 (CCL5), which binds to C-C chemokine receptor type 5 (CCR5) on cancer cells, and cancer cells release colony-stimulating factor 1 (CSF1), which binds to CSF1R on $\mathrm{MSCs}^{87}$. These two pathways are both dependent on HIF activity and promote the recruitment of tumorassociated macrophages (TAMs) and myeloid-derived suppressor cells (MDSCs) ${ }^{87}$. Hence, hypoxia induced by anti-angiogenic therapy could promote tumor invasion by accelerating the development of VM, vessel co-option, and EMT phenotypes. As mentioned above, the HIF- $1 \alpha$-ZEB2-ephrinB2 axis is an important regulatory pathway in promoting tumor invasiveness and evasive resistance in glioma during bevacizumab treatment ${ }^{49}$. Anti- angiogenic agents induced the accumulation of Tie2expressing macrophages (TEMs) at the invasive front of glioma tumor and TEMs can enhance the invasiveness of glioma tumor by secreting MMPs ${ }^{88}$. Altogether, these studies offer opportunities for overcoming invasion and metastasis resulting from antiangiogenic therapy.

\section{The role of stromal cells in resistance to anti-angiogenic therapy}

TME is composed of resident (ECs and fibroblasts) and infiltrating (lymphocytes and macrophages) cells, extracellular matrix (collagen and fibronectin), and released molecules (cytokines, chemokines, antibodies, proteases, and angiogenic factors). One possible mechanism for resistance to anti-angiogenic therapy might be due to the recruitment of stromal cells. We and others have studied the complex interplay between ECs, platelets, pericytes, cancer-associated fibroblasts (CAFs), and white blood cells in the context of response to anti-angiogenic therapy ${ }^{11,89}$.

\section{Endothelial cells}

The crosstalk between ECs and other stromal cells plays a critical role in response to anti-angiogenic therapy. Ang/Tie signaling is one of the central pathways that controls blood vessel growth, cell-cell interactions, and anti-angiogenic resistance. Ang2-regulated interactions between ECs and pericytes/myeloid cells are among the resistance mechanisms to anti-angiogenic therapy. For instance, bevacizumab could enhance Ang2/Tie2 signaling in ECs and upregulate Ang2 expression, which leads to reduced pericyte coverage and increased macrophage infiltration in brain cancer ${ }^{90}$. Heterogeneity of tumor ECs (TECs) might also contribute to resistance to anti-angiogenic therapy. TECs are different from normal ECs in many ways, including cell proliferation, migration, gene expression profile, and response to therapy. TECs are resistant to some chemotherapeutic drugs such as vincristine, 5-fluorouracil, and paclitaxel owing to the upregulation of drug resistance-associated genes ${ }^{91}$. CXCR4 is selectively expressed in TECs, and CXCR4 ${ }^{+}$TECs are related to poor outcome in patients with HCC. Functional studies revealed that CXCR4 is enriched in HCC angiogenic tip cells and overexpression of CXCR4 in ECs could stimulate vessel formation and sprouting in vivo and in vitro, implicating an important role for CXCR4 ${ }^{+}$TECs in angiogenesis ${ }^{92}$. Furthermore, sorafenib shows higher anti-tumor efficacy in HCC tumors with high $\mathrm{CXCR}^{+}{ }^{+}$expression ${ }^{92}$. Interestingly, the recruitment of collagen type $\mathrm{I}^{+} / \mathrm{CXCR} 4^{+}$fibrocyte-like cells can contribute to acquired resistance to bevacizumab ${ }^{93}$. The activation of $\mathrm{CXCR} 4$, mediated 
mainly by CXCL12 (ligand for CXCR4), is induced by HIF- $1 \alpha$ in hypoxic conditions ${ }^{93}$. Similarly, a CXCR4 antagonist could interfere with neovascularization by preventing the interaction of $\mathrm{CXCR}^{+}$bone marrow-derived myeloid cells (BMDCs) and SDF- $1 \alpha^{94}$. Collectively, these findings reveal potential markers for predicting response to anti-angiogenic therapy. Although the pathways by which TECs mediate resistance to anti-angiogenic therapy are not fully understood, such research holds promise for enhancing anti-angiogenic therapy.

\section{Tumor-associated macrophages}

BMDCs play a crucial role in the progression of angiogenesis and resistance to anti-angiogenic therapy. Many studies have shown that recruitment of BMDCs in GBM can cause resistance to vatalanib treatment and correspondingly the depletion of BMDCs can potentiate the effects of vatalanib ${ }^{95-97}$. Hypoxiaregulated neuropilin-1 (Nrp1), a marker of pro-angiogenic macrophages, can regulate the infiltration of TAMs into tumor hypoxic regions, and loss of $\mathrm{Nrp} 1$ in macrophages reduced angiogenesis and tumor growth ${ }^{98}$. Future studies are needed to determine whether Nrp1 contributes to the acquisition of resistance to angiogenesis inhibitors and the underlying mechanisms. Another study revealed that the recruitment of TAMs in bevacizumab-resistant xenografts is caused by proliferation of differentiated macrophages and macrophage polarization and increases in numbers of pro-angiogenic macrophages ${ }^{99}$. Bevacizumab can reduce macrophage inhibitory factor (MIF) expression at the edge of the tumor during early treatment while the loss of MIF leads to increased proliferation of TAMs in this area and eventual reprogramming into pro-angiogenic macrophages, even while treatment is continued ${ }^{99}$. Pro-angiogenic macrophages promote tumor growth and invasion by secreting factors (for example, VEGFA, tumor necrosis factor alpha [TNF $\alpha$ ], and interleukin-2 [IL-2]), eventually resulting in resistance to bevacizumab. In addition, hypoxia-induced chemokines (CXCL) and their receptors (CXCLR) have been shown to enhance the recruitment of TAMs and contribute to the emergence of therapeutic resistance ${ }^{89}$.

\section{Tie2-expressing macrophages}

TEMs are a subpopulation of TAMs. Crosstalk between TEMs and other stromal cells can enhance pro-angiogenic effects. For example, the interaction of TEMs and Tie $2^{+}$endothelial tip cells can promote vascular anastomoses during embryonic angiogenesis, and the blockade of the Ang2/Tie2 pathway in mannose receptor (MRC1)-expressing TEMs can impede angiogenesis ${ }^{100,101}$. In the RIP1-Tag2 pancreatic neuroendocrine tumor model, VEGFR2 inhibition upregulates Ang2 levels and enhances infiltration of TEMs. It can be halted by applying dual inhibitors of Ang2 and VEGFR2, which indicates that the adaptive enforcement of Ang2/Tie2 signaling induced by VEGFR inhibition may contribute to resistance ${ }^{102}$. Similarly, in a murine GBM mouse model, blockade of Ang2 and VEGF resulted in decreased vascular permeability, decreased TEMs, and increased pericyte coverage and intratumoral T lymphocytes. Ang2 comes mainly from ECs and can mediate the interaction of ECs and myeloid cells $^{90}$. A strategy of dual blockade of Ang2 and VEGFR has shown better vascular normalization and TAM-phenotype shift than single-agent therapy ${ }^{103}$. However, a recent phase II study showed that trebananib, an Ang1/2 inhibitor, was not effective as monotherapy in recurrent glioblastoma and did not improve outcomes in combination with bevacizumab. It is possible that such a dual inhibition strategy would be more effective in other cancer types $^{104}$.

\section{Pericytes}

Pericytes play an important role in angiogenesis and vessel maturation, although the specific mechanisms involved are only partially elucidated ${ }^{105}$. Angiogenic sprouting of ECs is facilitated by the detachment of pericytes, and vessel maturation requires the recruitment of supporting pericytes. The interactions between pericytes and ECs mediated by Ang/Tie signaling are a crucial step for blood vessel stabilization ${ }^{106,107}$. A previous study demonstrated a bidirectional, reciprocal relationship between ECs and pericytes via Ang/Tie2 signaling, as pericytes can also express functional Tie2 receptor ${ }^{108}$. Several studies have focused on elucidating the mechanisms of pericytes in vessel stabilization or dysfunction $^{106,109-111}$. In terms of whether targeting pericytes could alleviate resistance to anti-angiogenic therapy, there is variability in the preclinical data. Recruitment of pericytes to tumor blood vessels is mediated by PDGF signaling and dual targeting of VEGF-mediated angiogenesis, and PDGF-mediated pericyte recruitment was found to be more effective than targeting VEGF-mediated angiogenesis alone in a RIP1-Tag2 mouse model ${ }^{112}$. However, a subsequent study demonstrated that the absence of pericytes in tumors does not enhance the efficacy of anti-VEGF therapy in pericyte-deficient $p d g f b^{\text {ret ret }}$ mouse models ${ }^{113}$.

Several pericyte-targeted therapies (by targeting PDGFR, VEGFR, and Tie2) are aimed at reducing tumor angiogenesis by blocking EC-pericyte interactions ${ }^{114}$. For example, trebananib (Ang2 inhibitor) and nintedanib (VEGFR/FGFR/PDGFR inhibitor) show clinical benefits for patients with advanced ovarian cancer when combined with chemotherapy (Table 1). One study in patients with breast cancer has shown that an increased pericyte-covered microvascular density (MVD), a marker of vascular normalization, is associated with improved pathologic response during post-bevacizumab monotherapy ${ }^{115}$. Some studies suggest that pericytes can be used for predicting response to anti-angiogenic therapy. A retrospective study has revealed that $P D G F R-\beta$ which is related to pericyte maturation can predict bevacizumab efficacy in patients with colon cancer ${ }^{116}$. Similarly, it was shown that, in triple-negative breast cancer, tumors with high $\mathrm{PDGFR}^{+} /$low desmin ${ }^{+}$pericytes coverage were more responsive to anti-angiogenic therapy ${ }^{117}$. However, elucidating the mechanisms of pericytes mediating resistance to anti-angiogenic therapy still requires additional work.

\section{Endothelial progenitor cells}

Endothelial progenitor cells (EPCs) have been shown to promote the angiogenic switch in solid tumors, and the recruitment of EPCs from bone marrow can directly contribute to tumor development and colonization. The recruitment of EPCs is induced primarily by hypoxia, and their contribution to tumor vasculature might stimulate resistance to anti-VEGF therapies ${ }^{89,118}$. 
Various factors are involved in the activation and mobilization of EPCs, including HIF-1 $\alpha$, VEGF, SDF1, MMPs, and membrane -bound kit ligand $(\mathrm{mbKitL})^{89}$. A recent study showed that interactions between EPCs and ECs are independent of hypoxia and the pro-angiogenic effects of EPCs on ECs were not completely dependent on the presence of VEGFA ${ }^{119}$. Thus, VEGFindependent activation of EPCs could counteract the effects of anti-VEGF therapy and result in resistance. The circulating EPC frequency and the level of phospho-ERK in EPCs are a potential biomarker of sorafenib efficacy ${ }^{120}$.

\section{Myeloid-derived suppressor cells}

MDSCs can promote metastasis in animal models and cancer patients by supporting tumor cell survival, angiogenesis, invasion, and metastasis ${ }^{121,122}$. The role of immature myeloid cells/ MDSCs in mediating resistance to anti-angiogenic therapy was first reported in preclinical studies by Shojaei et al. ${ }^{123,124}$. It has been suggested that MDSCs cause tumor resistance to anti-angiogenic therapy in several different ways, including (i) enhanced recruitment and infiltration of MDSCs, (ii) altered gene expression, (iii) phenotype differentiation, and (iv) activation of alternative growth factors ${ }^{89,125-127}$. A persistence of intratumoral MDSCs is observed in sunitinib-resistant mouse models and may be related to local expression of granulocyte macrophage colony-stimulating factor (GM-CSF) and activation of STAT $5^{126}$. This is confirmed in patients with sunitinib-treated tumors that show persistent elevation in MDSCs with increasing levels of pro-angiogenic factors such as MMPs and IL- $8^{126}$. However, the detailed pathways of MDSC-mediated resistance to anti-angiogenic therapy and their clinical relevance are not fully understood.

\section{Platelets}

As a well-known mediator for thrombosis and hemostasis, platelets have been recognized as a critical component of angiogenesis, metastasis, and tumor progression via releasing pro-angiogenic and anti-angiogenic factors ${ }^{128,129}$. Although the functional role of platelets in regulating angiogenesis has been reviewed $^{130}$, little is known about the role of platelets in response to anti-angiogenic therapy. Platelets might mediate resistance to anti-angiogenic therapy by secreting various growth factors and cytokines, interaction with EPCs and pericytes, uptaking antiVEGF drugs, and promoting tumor invasion and metastasis ${ }^{89}$. Platelet contents such as PDGF, FGF, angiostatin, and insulinlike growth factor (IGF) contribute to the development of tumors by interacting with myeloid cells or stimulating angiogenic factors ${ }^{131,132}$. A recent study demonstrated that platelet releasate exhibits a powerful pro-angiogenic effect on GBM-derived ECs and contains a high level of VEGF in patients with GBM as compared with normal controls ${ }^{133}$.

\section{Other mechanisms}

CAFs play a critical role in the TME. The expression of SDF1 and PDGF-C in CAFs has been reported in drug-resistant tumors $^{89}$. Crawford et al. first reported a role of CAFs in mediating resistance to anti-angiogenic therapy in a preclinical study ${ }^{134}$. A recent study reported that CD $44^{+}$CAFs are increased following treatment with angiogenesis inhibitors and contribute to the maintenance of cancer stem cell populations, which associate with drug resistance ${ }^{135}$. Marrow-derived fibrocyte-like cells with expression of alpha-1 type I collagen and CXCR4 have been demonstrated to contribute to acquired resistance to bevacizumab by producing FGF $2^{93}$. Anti-angiogenic therapy has been shown to modulate and enhance the immune response in patients with cancer. For example, decreased regulatory $\mathrm{T}$ (Treg) cells have been noted during bevacizumab treatment in patients with mCRC and $\mathrm{GBM}^{136}$. Recent studies found that bevacizumab could increase $\mathrm{CD}^{+}$lymphopenia, which is associated with poor survival in GBM patients and immune response suppression ${ }^{136}$. However, another study showed that bevacizumab did not change the number, proliferation, or activation status in T-cell subsets within tumors but rather increased the percentage of M1/proinflammatory-polarized anti-tumor $\mathrm{TAMs}^{137}$. A similar study showed that bevacizumab did not increase circulating suppressive MDSCs (lineage-HLADR-CD $11 \mathrm{~b}^{+} \mathrm{CD} 33^{+}$) but can increase the circulating concentration of soluble VEGFA ${ }^{136}$.

\section{Targeting tumor microenvironment to overcome therapeutic resistance}

The compensatory mechanisms such as the expression of other pro-angiogenic factors, hypoxia, and the crosstalk between tumor and stromal cells can be a new target to overcome resistance to anti-angiogenesis therapy. The emerging strategies targeting TME include new specific inhibitors, combined pathway inhibitors, multi-targeting strategies, and new approaches for drug delivery.

\section{New inhibitors}

Several specific antagonists of $\operatorname{VEGF}(R)$ have been investigated in recent years. iVR1, a new inhibitor of VEGFR1, could inhibit colorectal cancer growth, macrophage migration, and monocyte mobilization by blocking the phosphorylation of VEGFR $1^{138}$. Meanwhile, new antibodies are being investigated to target different molecules except for VEGF. For example, monoclonal antibodies against endoglin (CD105), a protein receptor of the transforming growth factor-beta (TGF- $\beta$ ) superfamily, showed a promising anti-vascular effect ${ }^{139}$. A single-chain fragment of anti-human Ang2 has been shown to inhibit tumor growth, reduce vascular permeability, and extend survival in a bevacizumab-treatment GBM mouse model ${ }^{140}$. Delta-like ligand 4-NOTCH1 signaling has been demonstrated to mediate tumor resistance to anti-VEGF therapy in preclinical models by activating multiple pathways ${ }^{141}$. In preclinical ovarian cancer models, we have shown that dual targeting of DLL4 and VEGF exhibits superior anti-tumor effects ${ }^{142}$. Two humanized DLL4 antibodies-enoticumab (REGN421) and demcizumab (OMP21M18)- have shown preliminary anti-tumor activity in ovarian cancer and other solid tumors in phase I studies ${ }^{143,144}$. A bispecific DLL4/VEGF (OMP-305B83) antibody is also in phase Ib investigation with paclitaxel in ovarian cancer (ClinicalTrials.gov identifier: NCT03030287).

\section{Combined pathway inhibitors}

As hypoxia plays a critical role in cancer progression, metastasis, and resistance to anti-angiogenic therapy, the development of hypoxia inhibitors could be a powerful approach for cancer treatment. A novel small molecule named saltern amide A (SA) can inhibit HIF-1 $\alpha$ in various human cancer cells. SA suppressed 
PI3K/AKT/mTOR, p42/44 MAPK, and STAT3 signaling ${ }^{145}$. Results from a phase I trial of bortezomib (a HIF- $1 \alpha$ transcriptional activity suppressor) plus bevacizumab demonstrated clinical activity in patients with various tumors, including renal cell, breast, and ovarian/fallopian tube cancers ${ }^{146}$. A phase I study in a combination with bevacizumab and EZN-2208 (PEGylated SN-38), another HIF-1 $\alpha$ transcriptional activity inhibitor, showed acceptable toxicity in patients with refractory solid tumors. However, owing to the limited number of patients, the results did not demonstrate a conclusive effect of EZN-2208 on the activity of HIF- $1 \alpha^{147}$. The combination of an HDAC inhibitor and anti-angiogenic agents can downregulate HIF-1 $\alpha$ and VEGF expression $^{13}$. Similarly, another study showed that the combination of metronomic topotecan and pazopanib can improve treatment response compared with the single drugs alone in metastatic triple-negative breast cancer ${ }^{106}$. The potential mechanism might be related to the downregulation of HIF-1 $\alpha$ induced by low-dose, continuous topotecan treatment ${ }^{148}$. HIF- $1 \alpha$ dimerization inhibitor acriflavine can enhance the anti-tumor efficacy of sunitinib by inhibiting VEGF and TGF- $\beta$ expression and the accumulation of MDSCs in the spleen ${ }^{149}$.

Given the adaptation of the immune cells during anti-angiogenic therapy, combination of anti-angiogenic agents with immune drugs is being investigated. Immune checkpoint inhibitors such as ipilimumab, nivolumab, and pembrolizumab show promising anti-tumor effects by augmenting anti-tumor immune responses ${ }^{150,151}$. Programmed cell death-1 (PD-1) receptor, the negative immune checkpoint regulator, and its ligand, PD-L1, which can suppress immune response, have been shown to be upregulated during anti-angiogenic therapy ${ }^{152,153}$. Thus, it provides feasible approaches to enhance response to anti-angiogenic therapy by adding immune checkpoint inhibitors. Several studies have reported that adding immune checkpoint agents shows improved clinical benefit compared with anti-angiogenic monotherapy ${ }^{154}$. A2V, a novel bevacizumab-based bispecific human IgG1 antibody that targets Ang2 and VEGFA, has been found to promote anti-tumor immunity by activating tumorinfiltrating $\mathrm{CD}^{+} \mathrm{T}$ cells, increasing tumor antigen presentation, and enhancing perivascular T-cell accumulation ${ }^{152}$. Also, A2V can increase PD-L1 expression via interferon-gamma (IFN $\gamma$ ) signaling and combining PD-1 blockade and A2V can improve the anti-tumor activity in certain tumor models ${ }^{152}$. The enhanced effect of adding PD-L1 inhibitor to anti-angiogenic therapy is dependent on the induction of high endothelial venules, which can facilitate lymphocyte infiltration via lymphotoxin $\beta$ receptor signaling ${ }^{153}$. A series of clinical trials of combined anti-angiogenic therapy with immune checkpoint therapy is ongoing ${ }^{154}$.

As VEGF-independent angiogenesis pathways can contribute to resistance to anti-VEGF therapy, the combination treatment of chemotherapeutic agents and anti-VEGF therapy may overcome such drug resistance. A study of the combination of vascular disrupting agents (VDAs) and sunitinib was found to result in improved treatment efficacy in a colorectal liver metastasis mouse model by reducing tumor proliferation and vasculature and increasing tumor apoptosis ${ }^{155}$. Similarly, a phase II trial showed that the addition of VDAs to bevacizumab can extend PFS duration in patients with recurrent ovarian cancer ${ }^{30}$.
The combination of VEGF/VEGFR inhibitors with antiinvasive drugs or vessel co-option inhibitors may provide another possibility to overcome resistance. A recent phase I study in patients with recurrent GBM tested the combined effect of the VEGFR inhibitor cediranib with the invasion inhibitor cilengitide. Although no increased toxicities were observed in the combination treatment of cediranib and cilengitide, no survival benefit was shown ${ }^{156}$. However, recent preclinical work has shown that cilengitide can in fact promote tumor invasion, tumor growth, and tumor angiogenesis and therefore may not be the ideal drug to combine with anti-angiogenic therapy in the clinic $^{157,158}$. Despite the promising future of combining antiangiogenic therapy with anti-invasive agents or vessel cooption inhibitors, successful clinical translation has yet to be achieved.

\section{Multi-targeting strategy}

Based on the compensatory responses to anti-VEGF therapy, combining treatments that target multiple angiogenic signals could be important. Preclinical models showed that the combination of multi-tyrosine kinase inhibitors lenvatinib (VEGFR, FGFR, and RET inhibitor) and golvatinib (E7050; c-Met, Tie2, and EphB4 inhibitor) could inhibit the development of pericytes and infiltration of TEMs in thyroid and endometrial cancer models ${ }^{159}$. Apart from VEGF/VEGFR inhibitors, targeting PDGF/PDGFR signaling can also improve the efficacy of current therapy and reduce tumor growth, invasion, and metastasis ${ }^{160}$. Nonetheless, one study showed that the depletion of pericytes by imatinib and sunitinib not only can reduce tumor growth but also can increase metastasis and EMT progression ${ }^{161}$. Another

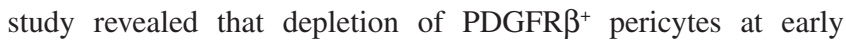
stages of tumor progression reduced metastasis but enhanced metastasis at later stages; further study implicated Ang2 as a key mediator of the metastatic phenotype ${ }^{162}$. Notably, the increased metastasis induced by pericyte depletion can be limited by additional MET or Ang2 inhibitors, which may provide a new and efficient strategy to suppress tumor growth while minimizing the risk of metastasis ${ }^{161,162}$. A heparin-derived angiogenesis inhibitor, LHT7, targeting FGF2 and PDGF- $\beta$, could inhibit the maturation of endothelium and can serve as a potential drug together with VEGF inhibitors to overcome resistance ${ }^{163}$. Further study indicated that the combination of LHT7 and a selective cyclooxygenase-2 (COX2) inhibitor (celecoxib) showed a stronger therapeutic effect than anti-angiogenic drugs alone ${ }^{164}$. COX2 has been reported to counteract the efficacy of anti-angiogenic agents ${ }^{164}$. Lucitanib (a multi-target inhibitor of VEGFR1 to 3, PDGFR $\alpha / \beta$, and FGFR1 to 3) has demonstrated activity in phase I/II clinical testing in patients with breast cancer ${ }^{165}$. Another novel method to overcome resistance to bevacizumab therapy is combining VEGF inhibitors with pericyte-targeted drugs (mostly inhibitors of Ang or PDGFR $\beta$ ). Ang2 and the VEGFA inhibitor A2V exert anti-tumor effects in a variety of ways, including impairing tumor angiogenesis, reducing metastasis, and increasing the infiltration of pro-inflammatory macrophages ${ }^{137,166}$. In a xenograft model of ovarian cancer, dual targeting of VEGF and Ang has been shown to result in greater inhibition of tumor angiogenesis and metastasis than monotherapy with either VEGF or Ang inhibitors ${ }^{167}$. Another study showed that VEGF inhibitor and Ang2 inhibitor can potentially reduce 
resistance to anti-angiogenic therapy ${ }^{90}$. Furthermore, imatinib could inhibit $\mathrm{PDGFR}^{+}$pericyte-like cells and disrupt tumor vascular integrity as well as EC survival ${ }^{168}$. While trebananib (a first-in-class peptibody targeting Ang2) exhibited clinical benefit in patients with ovarian cancer, it was ineffective as monotherapy and did not enhance the effect of bevacizumab in patients with recurrent glioblastoma ${ }^{104,169}$. As first-line therapy, brivanib (a dual inhibitor of VEGFR and FGFR) had a similar anti-tumor effect but was less well tolerated compared with sorafenib in a phase III study ${ }^{170}$. Another phase III study showed that brivanib as second-line therapy did not result in improved outcomes of HCC patients who did not respond to sorafenib ${ }^{171}$. Additional work is needed to understand the true efficacy of multi-targeted therapy in different cancer types.

\section{Drug delivery}

Nanoparticles can be designed with specific target proteins to deliver drugs into target cells. New sorafenib-loaded CXCR4targeted nanoparticles have been designed to treat HCC. The results of in vitro and in vivo studies show that it can reduce the infiltration of TAMs and enhance anti-angiogenic effects. Nanoparticles designed to deliver sorafenib into tumors efficiently could be an innovative approach to overcome drug resistance ${ }^{172}$.

\section{Conclusions}

Although mechanistic links between TME and anti-angiogenic therapy have been studied, the overall mechanisms of resistance to anti-angiogenic therapy require additional work. The combination of $\operatorname{VEGF}(\mathrm{R})$ inhibitors and other pathway inhibitors, including hypoxia inhibitors or immune checkpoint inhibitors, is being evaluated in various clinical trials. Unfortunately, reliable biomarkers for predicting response or the emergence of resistance have not been identified. It is likely that combination treatments will be required for overcoming drug resistance and prolonging patient survival. In summary, anti-angiogenesis therapies remain a highly effective avenue for cancer therapy. Understanding the mechanisms of adaptive resistance will allow an improved understanding of the complex underlying biology and holds tremendous potential for innovative drug development.

\section{Abbreviations}

Ang, angiopoietin; BMDC, bone marrow-derived cell; CA, carbonic anhydrase; CAF, cancer-associated fibroblast; COX2, cyclooxygenase-2; CSF1, colony-stimulating factor 1; CXCL, $\mathrm{C}-\mathrm{X}-\mathrm{C}$ chemokine ligand; $\mathrm{CXCR}, \mathrm{C}-\mathrm{X}-\mathrm{C}$ chemokine receptor; EC, endothelial cell; EMT, epithelial-to-mesenchymal transition; EPC, endothelial progenitor cell; FAK, focal adhesion kinase; FGF, fibroblast growth factor; FGFR, fibroblast growth factor receptor; FIH-1, factor inhibiting 1; GBM, glioblastoma multiforme; HCC, hepatocellular carcinoma; HDAC, histone deacetylase; HIF, hypoxia-inducible factor; IL, interleukin; mCRC, metastatic colorectal cancer; MAPK, mitogen-activated protein kinase; MDSC, myeloid-derived suppressor cell; MIF, macrophage inhibitory factor; MMP, matrix metalloproteinase; MSC, mesenchymal stem cell; mTOR, mammalian target of rapamycin; NAC1, nucleus accumbens-associated protein-1; Nrp1, neuropilin-1; OGDH, oxoglutarate dehydrogenase; OS, overall survival; PD-1, programmed cell death-1; PDGF, platelet-derived growth factor; PECAM, platelet endothelial cell adhesion molecule; PFS, progression-free survival; PHD, prolyl hydroxylase domain; ROS, reactive oxygen species; SA, saltern amide A; SDF1, stromal cell-derived factor 1; TAM, tumor-associated macrophage; TEC, tumor endothelial cell; TEM, Tie2-expressing macrophage; TGF- $\beta$, transforming growth factor-beta; TME, tumor microenvironment; VDA, vascular disrupting agent; VE-cadherin, vascular endothelial cadherin; VEGF/R, vascular endothelial growth factor/receptor; VM, vasculogenic mimicry

\section{Competing interests}

RLC has received grant funding from Genentech, Merck, Janssen, Clovis, AZ, and Abbvie and serves on the scientific steering committee as an investigator for Tesaro, Clovis, AZ, and Abbvie. AKS serves on the advisory board for Kiyatec and has received research funding from M-Trap. The other authors declare that they have no competing interests.

\section{Grant information}

Portions of this work were supported by the National Institutes of Health (P50 CA217685, P50 CA098258, CA177909, and R35 CA209904), the Frank McGraw Memorial Chair in Cancer Research, the Ann Rife Cox Chair in Gynecology, the American Cancer Society Research Professor Award, and the Institutional Core Grant (CA16672) to the MD Anderson Cancer Center from the National Institutes of Health.

The funders had no role in study design, data collection and analysis, decision to publish, or preparation of the manuscript.
1. Nandikolla AG, Rajdev L: Targeting angiogenesis in gastrointestinal tumors: current challenges. Transl Gastroenterol Hepatol. 2016; 1: 67. PubMed Abstract | Publisher Full Text | Free Full Text

2. Vasudev NS, Reynolds AR: Anti-angiogenic therapy for cancer: current progress, unresolved questions and future directions. Angiogenesis. 2014; 17(3): 471-94.

PubMed Abstract | Publisher Full Text | Free Full Text
3. Bergers G, Hanahan D: Modes of resistance to anti-angiogenic therapy. Nat Rev Cancer. 2008; 8(8): 592-603.

PubMed Abstract | Publisher Full Text | Free Full Text

4. Ebos JM, Kerbel RS: Antiangiogenic therapy: impact on invasion, disease progression, and metastasis. Nat Rev Clin Oncol. 2011; 8(4): 210-21. progression, and metastasis. Nat Rev Clin Oncol. 2011,
PubMed Abstract | Publisher Full Text | Free Full Text

5. Sennino B, McDonald DM: Controlling escape from angiogenesis inhibitors. Nat 
Rev Cancer. 2012; 12(10): 699-709.

PubMed Abstract | Publisher Full Text | Free Full Text

6. Hartmann S, Bhola NE, Grandis JR: HGF/Met Signaling in Head and Neck Cancer: Impact on the Tumor Microenvironment. Clin Cancer Res. 2016; 22(16): 4005-13.

PubMed Abstract | Publisher Full Text

7. F Torok S, Rezeli M, Kelemen O, et al.: Limited Tumor Tissue Drug Penetration Contributes to Primary Resistance against Angiogenesis Inhibitors.

Theranostics. 2017; 7(2): 400-412.

PubMed Abstract | Publisher Full Text | Free Full Text | F1000 Recommendation

8. Vaeteewoottacharn K, Kariya R, Dana P, et al:: Inhibition of carbonic anhydrase potentiates bevacizumab treatment in cholangiocarcinoma. Tumour Biol. 2016; 37(7): 9023-35.

PubMed Abstract | Publisher Full Text

9. Semenza GL: Regulation of oxygen homeostasis by hypoxia-inducible factor 1 . Physiology (Bethesda). 2009; 24: 97-106.

PubMed Abstract | Publisher Full Text

10. Muz B, de la Puente $\mathrm{P}$, Azab F, et al:: The role of hypoxia in cancer progression, angiogenesis, metastasis, and resistance to therapy. Hypoxia (Auckl). 2015; $\mathbf{3}$ : 83-92.

PubMed Abstract | Publisher Full Text | Free Full Text

11. Ulivi P, Marisi G, Passardi A: Relationship between hypoxia and response to antiangiogenic therapy in metastatic colorectal cancer. Oncotarget. 2016; 7(29): 46678-46691.

PubMed Abstract | Publisher Full Text | Free Full Text

12. Ellis L, Hammers H, Pili R: Targeting tumor angiogenesis with histone deacetylase inhibitors. Cancer Lett. 2009; 280(2): 145-53. PubMed Abstract | Publisher Full Text | Free Full Text

13. F Aggarwal R, Thomas S, Pawlowska N, et al:: Inhibiting Histone Deacetylase as a Means to Reverse Resistance to Angiogenesis Inhibitors: Phase I Study of Abexinostat Plus Pazopanib in Advanced Solid Tumor Malignancies. J Clin Oncol. 2017; 35(11): 1231-1239.

PubMed Abstract | Publisher Full Text | Free Full Text | F1000 Recommendation

14. Tavallai S, Hamed HA, Grant S, et al:: Pazopanib and HDAC inhibitors interact to kill sarcoma cells. Cancer Biol Ther. 2014; 15(5): 578-85. PubMed Abstract | Publisher Full Text | Free Full Text

15. F Zhang Y, Ren YJ, Guo LC, et al.: Nucleus accumbens-associated protein-1 promotes glycolysis and survival of hypoxic tumor cells via the HDAC4-HIF-1a axis. 2017.

PubMed Abstract | Publisher Full Text | Free Full Text | F1000 Recommendation

16. Abounader R, Laterra J: Scatter factor/hepatocyte growth factor in brain tumor growth and angiogenesis. Neuro Oncol. 2005; 7(4): 436-51.

PubMed Abstract | Publisher Full Text | Free Full Text

17. $\mathrm{F}$ Pennacchietti $\mathrm{S}$, Michieli $\mathrm{P}$, Galluzzo M, et al.: Hypoxia promotes invasive growth by transcriptional activation of the met protooncogene. Cancer Cell. 2003; 3(4): 347-61.

PubMed Abstract | Publisher Full Text | F1000 Recommendation

18. Jeon HM, Lee J: MET: roles in epithelial-mesenchymal transition and cancer stemness. Ann Transl Med. 2017; 5(1): 5.

PubMed Abstract | Publisher Full Text | Free Full Text

19. Qin Y, Roszik J, Chattopadhyay C, et al:: Hypoxia-Driven Mechanism of Vemurafenib Resistance in Melanoma. Mol Cancer Ther. 2016; 15(10): 2442-2454.

PubMed Abstract | Publisher Full Text | Free Full Text

20. Jahangiri A, De Lay M, Miller LM, et al.: Gene expression profile identifies tyrosine kinase c-Met as a targetable mediator of antiangiogenic therapy resistance. Clin Cancer Res. 2013; 19(7): 1773-83.

PubMed Abstract | Publisher Full Text | Free Full Text

21. F Daudigeos-Dubus E, Le Dret L, Bawa O, et al:: Dual inhibition using cabozantinib overcomes HGF/MET signaling mediated resistance to panVEGFR inhibition in orthotopic and metastatic neuroblastoma tumors. Int Oncol. 2017; 50(1): 203-211.

PubMed Abstract | Publisher Full Text | F1000 Recommendation

22. Coleman RL, Brady MF, Herzog TJ, et al.: Bevacizumab and paclitaxelcarboplatin chemotherapy and secondary cytoreduction in recurrent, platinum-sensitive ovarian cancer (NRG Oncology/Gynecologic Oncology Group study GOG-0213): a multicentre, open-label, randomised, phase 3 trial. Lancet Oncol. 2017; 18(6): 779-791.

PubMed Abstract | Publisher Full Text | Free Full Text

23. Marth C, Vergote I, Scambia G, et al:: ENGOT-ov-6/TRINOVA-2: Randomised, double-blind, phase 3 study of pegylated liposomal doxorubicin plus trebananib or placebo in women with recurrent partially platinum-sensitive or resistant ovarian cancer. Eur J Cancer. 2017; 70: 111-121.

PubMed Abstract | Publisher Full Text

24. Monk BJ, Poveda A, Vergote I, et al.: Anti-angiopoietin therapy with trebananib for recurrent ovarian cancer (TRINOVA-1): a randomised, multicentre, doubleblind, placebo-controlled phase 3 trial. Lancet Oncol. 2014; 15(8): 799-808. PubMed Abstract | Publisher Full Text

25. F Aghajanian C, Blank SV, Goff BA, et al:: OCEANS: a randomized, doubleblind, placebo-controlled phase III trial of chemotherapy with or without bevacizumab in patients with platinum-sensitive recurrent epithelial ovarian, primary peritoneal, or fallopian tube cancer. J Clin Oncol. 2012; 30(17): 2039-45. PubMed Abstract | Publisher Full Text | Free Full Text | F1000 Recommendation

26. Aghajanian $C$, Goff $B$, Nycum LR, et al.: Final overall survival and safety analysis of OCEANS, a phase 3 trial of chemotherapy with or without bevacizumab in patients with platinum-sensitive recurrent ovarian cancer. Gynecol Oncol. 2015; 139(1): 10-6.

PubMed Abstract | Publisher Full Text | Free Full Text

27. F Pujade-Lauraine E, Hilpert F, Weber B, et al:: Bevacizumab combined with chemotherapy for platinum-resistant recurrent ovarian cancer: The AURELIA open-label randomized phase III trial. J Clin Oncol. 2014; 32(13): 1302-8. PubMed Abstract | Publisher Full Text | F1000 Recommendation

28. Oza AM, Cook AD, Pfisterer J, et al.: Standard chemotherapy with or without bevacizumab for women with newly diagnosed ovarian cancer (ICON7): overal survival results of a phase 3 randomised trial. Lancet Oncol. 2015; 16(8): 92836.

PubMed Abstract | Publisher Full Text | Free Full Text

29. Ledermann JA, Embleton AC, Raja F, et al:: Cediranib in patients with relapsed platinum-sensitive ovarian cancer (ICON6): a randomised, double-blind, placebo-controlled phase 3 trial. Lancet. 2016; 387(10023): 1066-74. PubMed Abstract | Publisher Full Text

30. $\quad F$ Monk BJ, Sill MW, Walker JL, et al.: Randomized Phase II Evaluation of Bevacizumab Versus Bevacizumab Plus Fosbretabulin in Recurrent Ovarian, Tubal, or Peritoneal Carcinoma: An NRG Oncology/Gynecologic Oncology Group Study. J Clin Oncol. 2016; 34(19): 2279-86.

PubMed Abstract | Publisher Full Text | Free Full Text | F1000 Recommendation

1. du Bois A, Kristensen G, Ray-Coquard I, et al.: Standard first-line chemotherapy with or without nintedanib for advanced ovarian cancer (AGO-OVAR 12): a randomised, double-blind, placebo-controlled phase 3 trial. Lancet Oncol. 2016; 17(1): 78-89.

PubMed Abstract | Publisher Full Text

32. F Tewari KS, Sill MW, Long HJ 3rd, et al.: Improved survival with bevacizumab in advanced cervical cancer. N Engl J Med. 2014; 370(8): 734-43. PubMed Abstract | Publisher Full Text | Free Full Text | F1000 Recommendation

33. Symonds RP, Gourley C, Davidson S, et al:: Cediranib combined with carboplatin and paclitaxel in patients with metastatic or recurrent cervical cancer (CIRCCa): a randomised, double-blind, placebo-controlled phase 2 trial. Lancet Oncol. 2015; 16(15): 1515-24. PubMed Abstract | Publisher Full Text | Free Full Text

34. Takeda M, Yamanaka T, Seto T, et al.: Bevacizumab beyond disease progression after first-line treatment with bevacizumab plus chemotherapy in advanced nonsquamous non-small cell lung cancer (West Japan Oncology Group 5910L): An open-label, randomized, phase 2 trial. Cancer. 2016; 122(7): $1050-9$.

PubMed Abstract | Publisher Full Text

35. Zhou C, Wu YL, Chen G, et al:: BEYOND: A Randomized, Double-Blind, PlaceboControlled, Multicenter, Phase III Study of First-Line Carboplatin/Paclitaxel Plus Bevacizumab or Placebo in Chinese Patients With Advanced or Recurrent Nonsquamous Non-Small-Cell Lung Cancer. J Clin Oncol. 2015; 33(19): 2197-204.

PubMed Abstract | Publisher Full Text

36. Pujol JL, Lavole A, Quoix E, et al:: Randomized phase II-III study of bevacizumab in combination with chemotherapy in previously untreated extensive smallcell lung cancer: results from the IFCT-0802 trial. Ann Oncol. 2015; 26(5): 908-14.

PubMed Abstract | Publisher Full Text

37. Tournigand C, Chibaudel B, Samson B, et al.: Bevacizumab with or without erlotinib as maintenance therapy in patients with metastatic colorectal cancer (GERCOR DREAM; OPTIMOX3): a randomised, open-label, phase 3 trial. Lancet Oncol. 2015; 16(15): 1493-505.

PubMed Abstract | Publisher Full Text

38. Tabernero J, Yoshino T, Cohn AL, et al.: Ramucirumab versus placebo in combination with second-line FOLFIRI in patients with metastatic colorectal carcinoma that progressed during or after first-line therapy with bevacizumab, oxaliplatin, and a fluoropyrimidine (RAISE): a randomised, double-blind, multicentre, phase 3 study. Lancet Oncol. 2015; 16(5): 499-508. PubMed Abstract | Publisher Full Text

39. Martín M, Loibl S, von Minckwitz G, et al.: Phase III trial evaluating the addition of bevacizumab to endocrine therapy as first-line treatment for advanced breas cancer: the letrozole/fulvestrant and avastin (LEA) study. J Clin Oncol. 2015; 33(9): 1045-52. PubMed Abstract | Publisher Full Text

40. Balana C, De Las Penas R, Sepúlveda JM, et al:: Bevacizumab and temozolomide versus temozolomide alone as neoadjuvant treatment in unresected glioblastoma: the GENOM 009 randomized phase II trial. $J$ Neurooncol. 2016; 127(3): 569-79. PubMed Abstract | Publisher Full Text

41. Haas NB, Manola J, Uzzo RG, et al:: Adjuvant sunitinib or sorafenib for highrisk, non-metastatic renal-cell carcinoma (ECOG-ACRIN E2805): a doubleblind, placebo-controlled, randomised, phase 3 trial. Lancet. 2016; 387(10032): 2008-16.

PubMed Abstract | Publisher Full Text | Free Full Text

42. Choueiri TK, Halabi S, Sanford BL, et al:: Cabozantinib Versus Sunitinib As Initial Targeted Therapy for Patients With Metastatic Renal Cell Carcinoma of Poor 
or Intermediate Risk: The Alliance A031203 CABOSUN Trial. J Clin Oncol. 2017 35(6): 591-597.

PubMed Abstract | Publisher Full Text | Free Full Text

43. Choueiri TK, Escudier B, Powles T, et al.: Cabozantinib versus everolimus in advanced renal cell carcinoma (METEOR): final results from a randomised, open-label, phase 3 trial. Lancet Oncol. 2016; 17(7): 917-27.

PubMed Abstract | Publisher Full Text

44. Daud A, Kluger HM, Kurzrock R, et al:: Phase II randomised discontinuation tria of the MET/VEGF receptor inhibitor cabozantinib in metastatic melanoma. $B r$ Cancer. 2017; 116(4): 432-440.

PubMed Abstract | Publisher Full Text | Free Full Text

45. Zalcman G, Mazieres J, Margery J, et al: Bevacizumab for newly diagnosed pleural mesothelioma in the Mesothelioma Avastin Cisplatin Pemetrexed Study (MAPS): a randomised, controlled, open-label, phase 3 trial. Lancet 2016; 387(10026): 1405-14

PubMed Abstract | Publisher Full Text

46. Hensley ML, Miller A, O'Malley DM, et al.: Randomized phase III trial of gemcitabine plus docetaxel plus bevacizumab or placebo as first-line treatment for metastatic uterine leiomyosarcoma: an NRG Oncology/ Gynecologic Oncology Group study. J Clin Oncol. 2015; 33(10): 1180-5. PubMed Abstract | Publisher Full Text | Free Full Text

47. Kawai A, Araki N, Hiraga $\mathrm{H}$, et al:: A randomized, double-blind, placebocontrolled, Phase III study of pazopanib in patients with soft tissue sarcoma: results from the Japanese subgroup. Jpn J Clin Oncol. 2016; 46(3): 248-53. PubMed Abstract | Publisher Full Text | Free Full Text

48. Sidorov M, Jahangiri A, Han SW, et al:: $\mathbf{3 4 0}$ c-Met//1 Integrin: A Receptor Complex Driving Invasive Glioblastoma Resistance to Antiangiogenic Therapy. Neurosurgery. 2016; 63 Suppl1: 199-200.

PubMed Abstract | Publisher Full Text

49. Depner C, Zum Buttel H, Böğürcü N, et al:: EphrinB2 repression through ZEB2 mediates tumour invasion and anti-angiogenic resistance. Nat Commun. 2016; 7: 12329

PubMed Abstract | Publisher Full Text | Free Full Text

50. Jahangiri A, Chen W, Yagnik G, et al:: 333 Obtaining the Genetic Fingerprint of Resistance to Glioblastoma Through a Novel Multigenerational Xenograft Model. Neurosurgery. 2016; 63 Suppl1: 197

PubMed Abstract | Publisher Full Text

51. Sennino B, Ishiguro-Oonuma $\mathrm{T}$, Wei $\mathrm{Y}$, et al:: Suppression of tumor invasion and metastasis by concurrent inhibition of c-Met and VEGF signaling in pancreatic neuroendocrine tumors. Cancer Discov. 2012; 2(3): 270-87. PubMed Abstract | Publisher Full Text | Free Full Text

52. F Lu KV, Chang JP, Parachoniak CA, et al.: VEGF inhibits tumor cell invasion and mesenchymal transition through a MET/VEGFR2 complex. Cancer Cell. 2012; 22(1): 21-35

PubMed Abstract | Publisher Full Text | Free Full Text | F1000 Recommendation

53. F Escudier B, Powles T, Motzer RJ, et al.: Cabozantinib, a New Standard of Care for Patients With Advanced Renal Cell Carcinoma and Bone Metastases? Subgroup Analysis of the METEOR Trial. J Clin Oncol. 2018; 36(8): 765-772. PubMed Abstract | Publisher Full Text | F1000 Recommendation

54. F Choueiri TK, Vaishampayan U, Rosenberg JE, et al.: Phase II and biomarke study of the dual MET/VEGFR2 inhibitor foretinib in patients with papillary renal cell carcinoma. J Clin Oncol. 2013; 31(2): 181-6.

PubMed Abstract | Publisher Full Text | Free Full Text | F1000 Recommendation

55. Delgado-Bellido D, Serrano-Saenz S, Fernández-Cortés M, et al.: Vasculogenic mimicry signaling revisited: focus on non-vascular VE-cadherin. Mol Cancer. 2017; 16(1): 65.

PubMed Abstract | Publisher Full Text | Free Full Text

56. Qiao L, Liang N, Zhang J, et al:: Advanced research on vasculogenic mimicry in cancer. J Cell Mol Med. 2015: 19(2): 315-26.

PubMed Abstract | Publisher Full Text | Free Full Text

57. Li S, Meng W, Guan Z, et al:: The hypoxia-related signaling pathways of vasculogenic mimicry in tumor treatment. Biomed Pharmacother. 2016; 80 127-35. PubMed Abstract | Publisher Full Text

58. F Serova M, Tijeras-Raballand A, Dos Santos C, et al: Everolimus affects vasculogenic mimicry in renal carcinoma resistant to sunitinib. Oncotarget 2016; 7(25): 38467-86.

PubMed Abstract | Publisher Full Text | Free Full Text | F1000 Recommendation

59. DeLisser HM, Christofidou-Solomidou M, Strieter RM, et al: Involvement of endothelial PECAM-1/CD31 in angiogenesis. Am J Pathol. 1997; 151(3): 671-7. PubMed Abstract | Free Full Text

60. Dunleavey JM, Xiao L, Thompson J, et al:: Vascular channels formed by subpopulations of PECAM1+ melanoma cells. Nat Commun. 2014; 5: 5200. PubMed Abstract | Publisher Full Text | Free Full Text

61. Sun $\mathrm{H}$, Zhang $\mathrm{D}, \mathrm{Yao} \mathrm{Z}$, et al:: Anti-angiogenic treatment promotes triplenegative breast cancer invasion via vasculogenic mimicry. Cancer Biol Ther. 2017; 18(4): 205-213

PubMed Abstract | Publisher Full Text | Free Full Text

62. Macklin PS, McAuliffe J, Pugh CW, et al:: Hypoxia and HIF pathway in cancer and the placenta. Placenta. 2017; 56: 8-13. PubMed Abstract | Publisher Full Text

63. Donnem T, Hu J, Ferguson M, et al:: Vessel co-option in primary human tumors and metastases: an obstacle to effective anti-angiogenic treatment? Cancer
Med. 2013; 2(4): 427-36.

PubMed Abstract | Publisher Full Text | Free Full Tex

64. Pinto MP, Sotomayor P, Carrasco-Avino G, et al.: Escaping Antiangiogenic Therapy: Strategies Employed by Cancer Cells. Int J Mol Sci 2016; 17(9): pii: E1489.

PubMed Abstract | Publisher Full Text | Free Full Text

65. Jeong HS, Jones D, Liao S, et al:: Investigation of the Lack of Angiogenesis in the Formation of Lymph Node Metastases. J Natl Cancer Inst. 2015; 107(9): pii: djv155.

PubMed Abstract | Publisher Full Text | Free Full Text

66. Leenders WP, Küsters B, Verrijp K, et al:: Antiangiogenic therapy of cerebral melanoma metastases results in sustained tumor progression via vessel cooption. Clin Cancer Res. 2004; 10(18 Pt 1): 6222-30.

PubMed Abstract | Publisher Full Text

67. Rubenstein JL, Kim J, Ozawa T, et al:: Anti-VEGF antibody treatment of glioblastoma prolongs survival but results in increased vascular cooption. Neoplasia. 2000; 2(4): 306-14. PubMed Abstract | Publisher Full Text | Free Full Text

68. F Bridgeman VL, Vermeulen PB, Foo S, et al:: Vessel co-option is common in human lung metastases and mediates resistance to anti-angiogenic therapy in preclinical lung metastasis models. J Pathol. 2017; 241(3): 362-374. PubMed Abstract | Publisher Full Text | Free Full Text | F1000 Recommendation

69. Szabo V, Bugyik E, Dezso K, et al:: Mechanism of tumour vascularization in experimental lung metastases. J Pathol. 2015; 235(3): 384-96. PubMed Abstract | Publisher Full Text

70. F Kuczynski EA, Yin M, Bar-Zion A, et al.: Co-option of Liver Vessels and Not Sprouting Angiogenesis Drives Acquired Sorafenib Resistance in Hepatocellular Carcinoma. J Natl Cancer Inst. 2016; 108(8): djw030. PubMed Abstract | Publisher Full Text | Free Full Text | F1000 Recommendation

71. F Pàez-Ribes M, Allen E, Hudock J, et al:: Antiangiogenic therapy elicits malignant progression of tumors to increased local invasion and distant metastasis. Cancer Cell. 2009; 15(3): 220-31.

PubMed Abstract | Publisher Full Text | Free Full Text | F1000 Recommendation

72. van Malenstein H, Dekervel J, Verslype $\mathrm{C}$, et al.: Long-term exposure to sorafenib of liver cancer cells induces resistance with epithelial-to-mesenchymal transition, increased invasion and risk of rebound growth. Cancer Lett. 2013; 329(1): 74-83.

PubMed Abstract | Publisher Full Text

73. F Frentzas S, Simoneau E, Bridgeman VL, et al:: Vessel co-option mediates resistance to anti-angiogenic therapy in liver metastases. Nat Med. 2016; 22(11): 1294-1302.

PubMed Abstract | Publisher Full Text | Free Full Text | F1000 Recommendation

74. Nakajima EC, Van Houten B: Metabolic symbiosis in cancer: refocusing the Warburg lens. Mol Carcinog. 2013; 52(5): 329-37. PubMed Abstract | Publisher Full Text

75. F Guillaumond F, Leca J, Olivares $\mathrm{O}$, et al:: Strengthened glycolysis under hypoxia supports tumor symbiosis and hexosamine biosynthesis in pancreatic adenocarcinoma. Proc Natl Acad Sci U S A. 2013; 110(10): 3919-24. PubMed Abstract | Publisher Full Text | Free Full Text | F1000 Recommendation

76. Pisarsky L, Bill R, Fagiani E, et al.: Targeting Metabolic Symbiosis to Overcome Resistance to Anti-angiogenic Therapy. Cell Rep. 2016; 15(6): 1161-74. PubMed Abstract | Publisher Full Text | Free Full Text

77. F Allen E, Miéville P, Warren CM, et al:: Metabolic Symbiosis Enables Adaptive Resistance to Anti-angiogenic Therapy that Is Dependent on mTOR Signaling. Cell Rep. 2016; 15(6): 1144-60.

PubMed Abstract | Publisher Full Text | Free Full Text | F1000 Recommendation

78. F Jiménez-Valerio G, Martínez-Lozano M, Bassani N, et al:: Resistance to Antiangiogenic Therapies by Metabolic Symbiosis in Renal Cell Carcinoma PDX Models and Patients. Cell Rep. 2016; 15(6): 1134-43.

PubMed Abstract | Publisher Full Text | Free Full Text | F1000 Recommendation

79. $\mathrm{F}$ Chen $\mathrm{CH}$, Fong LWR, Yu E, et al:: Upregulation of MARCKS in kidney cancer and its potential as a therapeutic target. Oncogene. 2017; 36(25): 3588-3598.

PubMed Abstract | Publisher Full Text | F1000 Recommendation

80. McElroy GS, Chandel NS: Mitochondria control acute and chronic responses to hypoxia. Exp Cell Res. 2017; 356(2): 217-222. PubMed Abstract | Publisher Full Text | Free Full Text

81. F Harel S, Mayaki D, Sanchez V, et al: NOX2, NOX4, and mitochondrialderived reactive oxygen species contribute to angiopoietin-1 signaling and angiogenic responses in endothelial cells. Vascul Pharmacol. 2017; 92: 22-32. PubMled Abstract | Publisher Full Text | F1000 Recommendation

82. $\mathrm{F}$ Navarro $\mathrm{P}$, Bueno MJ, Zagorac I, et al.: Targeting Tumor Mitochondrial Metabolism Overcomes Resistance to Antiangiogenics. Cell Rep. 2016; 15(12): 2705-18.

PubMed Abstract | Publisher Full Text | F1000 Recommendation

83. Burr SP, Costa AS, Grice GL, et al.: Mitochondrial Protein Lipoylation and the 2-Oxoglutarate Dehydrogenase Complex Controls HIF1 $\alpha$ Stability in Aerobic Conditions. Cell Metab. 2016; 24(5): 740-752

PubMed Abstract | Publisher Full Text | Free Full Tex

84. F Ebos JM, Lee CR, Cruz-Munoz M, et al: Accelerated metastasis after short- 
term treatment with a potent inhibitor of tumor angiogenesis. Cancer Cell. 2009; 15(3): 232-9.

PubMed Abstract | Publisher Full Text | Free Full Text | F1000 Recommendation

85. Singleton DC, Rouhi $\mathrm{P}$, Zois CE, et al:: Hypoxic regulation of RIOK3 is a major mechanism for cancer cell invasion and metastasis. Oncogene. 2015; 34(36): 4713-22.

PubMed Abstract | Publisher Full Text | Free Full Text

86. Hwang-Verslues WW, Chang PH, Jeng YM, et al: Loss of corepressor PER2 under hypoxia up-regulates OCT1-mediated EMT gene expression and enhances tumor malignancy. Proc Natl Acad Sci U S A. 2013; 110(30): 12331-6. PubMed Abstract | Publisher Full Text | Free Full Text

87. Chaturvedi P, Gilkes DM, Takano N, et al: Hypoxia-inducible factor-dependent signaling between triple-negative breast cancer cells and mesenchymal stem cells promotes macrophage recruitment. Proc Natl Acad Sci U S A. 2014 111(20): E2120-9.

PubMed Abstract | Publisher Full Text | Free Full Text

88. Gabrusiewicz K, Liu D, Cortes-Santiago N, et al.: Anti-vascular endothelial growth factor therapy-induced glioma invasion is associated with accumulation of Tie2-expressing monocytes. Oncotarget. 2014; 5(8): 2208-20. PubMed Abstract | Publisher Full Text | Free Full Text

89. Huijbers EJ, van Beijnum JR, Thijssen VL, et al:: Role of the tumor stroma in resistance to anti-angiogenic therapy. Drug Resist Updat. 2016; 25: 26-37. PubMed Abstract | Publisher Full Text

90. F Scholz A, Harter PN, Cremer S, et al.: Endothelial cell-derived angiopoietin-2 is a therapeutic target in treatment-naive and bevacizumab-resistant glioblastoma. EMBO Mol Med. 2016; 8(1): 39-57.

PubMed Abstract | Publisher Full Text | Free Full Text | F1000 Recommendation

91. Hida K, Maishi N, Sakurai $\mathrm{Y}$, et al:: Heterogeneity of tumor endothelial cells and drug delivery. Adv Drug Deliv Rev. 2016; 99(Pt B): 140-7. PubMed Abstract | Publisher Full Text

92. $F$ Xu J, Liang J, Meng YM, et al.: Vascular CXCR4 expression promotes vessel sprouting and sensitivity to sorafenib treatment in hepatocellular carcinoma. Clin Cancer Res. 2017; 23(15): 4482-4492.

PubMed Abstract | Publisher Full Text | F1000 Recommendation

93. Mitsuhashi A, Goto H, Saijo A, et al.: Fibrocyte-like cells mediate acquired resistance to anti-angiogenic therapy with bevacizumab. Nat Commun. 2015; 6 : 8792.

PubMed Abstract | Publisher Full Text | Free Full Text

94. Kioi M, Vogel H, Schultz G, et al.: Inhibition of vasculogenesis, but not angiogenesis, prevents the recurrence of glioblastoma after irradiation in mice. J Clin Invest. 2010; 120(3): 694-705

PubMed Abstract | Publisher Full Text | Free Full Text

95. F Shaaban S, Alsulami M, Arbab SA, et al.: Targeting Bone Marrow to Potentiate the Anti-Tumor Effect of Tyrosine Kinase Inhibitor in Preclinical Rat Model of Human Glioblastoma. Int J Cancer Res. 2016; 12(2): 69-81. PubMed Abstract | Publisher Full Text | Free Full Text | F1000 Recommendation

96. Ali MM, Kumar S, Shankar A, et al.: Effects of tyrosine kinase inhibitors and CXCR4 antagonist on tumor growth and angiogenesis in rat glioma model: MRI and protein analysis study. Transl Oncol. 2013; 6(6): 660-9. PubMed Abstract | Publisher Full Text | Free Full Text

97. Achyut BR, Shankar A, Iskander AS, et al:: Bone marrow derived myeloid cells orchestrate antiangiogenic resistance in glioblastoma through coordinated molecular networks. Cancer Lett. 2015; 369(2): 416-26. PubMed Abstract | Publisher Full Text | Free Full Text

98. F Casazza A, Laoui D, Wenes $\mathrm{M}$, et al.: Impeding macrophage entry into hypoxic tumor areas by Sema3A/Nrp1 signaling blockade inhibits angiogenesis and restores antitumor immunity. Cancer Cell. 2013; 24(6): 695709 .

PubMed Abstract | Publisher Full Text | F1000 Recommendation

99. F Castro BA, Flanigan $\mathrm{P}$, Jahangiri A, et al:: Macrophage migration inhibitory factor downregulation: a novel mechanism of resistance to anti-angiogenic therapy. Oncogene. 2017; 36(26): 3749-3759.

PubMed Abstract | Publisher Full Text | Free Full Text | F1000 Recommendation

100. F Mazzieri R, Pucci F, Moi D, et al.: Targeting the ANG2/TIE2 axis inhibits tumor growth and metastasis by impairing angiogenesis and disabling rebounds of proangiogenic myeloid cells. Cancer Cell. 2011; 19(4): 512-26. PubMed Abstract | Publisher Full Text | F1000 Recommendation

101. F Fantin A, Vieira JM, Gestri G, et al:: Tissue macrophages act as cellula chaperones for vascular anastomosis downstream of VEGF-mediated endothelial tip cell induction. Blood. 2010; 116(5): 829-40. PubMed Abstract | Publisher Full Text | Free Full Text | F1000 Recommendation

102. Rigamonti N, Kadioglu E, Keklikoglou I, et al.: Role of angiopoietin-2 in adaptive tumor resistance to VEGF signaling blockade. Cell Rep. 2014; 8(3): 696-706. PubMed Abstract | Publisher Full Text

103. F Peterson TE, Kirkpatrick ND, Huang Y, et al:: Dual inhibition of Ang-2 and VEGF receptors normalizes tumor vasculature and prolongs survival in glioblastoma by altering macrophages. Proc Natl Acad Sci U S A. 2016; 113(16): $4470-5$.

PubMed Abstract | Publisher Full Text | Free Full Text | F1000 Recommendation
104. F Reardon DA, Lassman AB, Schiff D, et al:: Phase $\mathbf{2}$ and biomarker study of trebananib, an angiopoietin-blocking peptibody, with and without bevacizumab for patients with recurrent glioblastoma. Cancer. 2017. PubMed Abstract | Publisher Full Text | F1000 Recommendation

105. Stapor PC, Sweat RS, Dashti DC, et al.: Pericyte dynamics during angiogenesis: new insights from new identities. J Vasc Res. 2014; 51(3): 163-74. PubMed Abstract | Publisher Full Text | Free Full Text

106. Caporali A, Martello A, Miscianinov V, et al.: Contribution of pericyte paracrine regulation of the endothelium to angiogenesis. Pharmacol Ther. 2017; 171: $56-64$

PubMed Abstract | Publisher Full Text

107. Kang E, Shin JW: Pericyte-targeting drug delivery and tissue engineering. Int $J$ Nanomedicine. 2016; 11: 2397-406. PubMed Abstract | Publisher Full Text | Free Full Text

108. F Teichert M, Milde L, Holm A, et al:: Pericyte-expressed Tie2 controls angiogenesis and vessel maturation. Nat Commun. 2017; 8: 16106. PubMed Abstract | Publisher Full Text | Free Full Text | F1000 Recommendation

109. Herbert SP, Stainier DY: Molecular control of endothelial cell behaviour during blood vessel morphogenesis. Nat Rev Mol Cell Biol. 2011; 12(9): 551-64. PubMed Abstract | Publisher Full Text | Free Full Text

110. F Hosono J, Morikawa S, Ezaki T, et al:: Pericytes promote abnormal tumor angiogenesis in a rat RG2 glioma model. Brain Tumor Pathol. 2017; 34(3): $120-129$

PubMed Abstract | Publisher Full Text | F1000 Recommendation

111. $\mathrm{F}$ Zhang $\mathrm{L}$, Wang $\mathrm{Y}$, Rashid $\mathrm{MH}$, et al:: Malignant pericytes expressing GT198 give rise to tumor cells through angiogenesis. Oncotarget. 2017; 8(31): 51591-51607

PubMed Abstract | Publisher Full Text | Free Full Text | F1000 Recommendation

112. Bergers G, Song S, Meyer-Morse N, et al:: Benefits of targeting both pericytes and endothelial cells in the tumor vasculature with kinase inhibitors. J Clin Invest. 2003; 111(9): 1287-95.

PubMed Abstract | Publisher Full Text | Free Full Text

113. Nisancioglu MH, Betsholtz C, Genové G: The absence of pericytes does not increase the sensitivity of tumor vasculature to vascular endothelial growth factor-A blockade. Cancer Res. 2010; 70(12): 5109-15. PubMed Abstract | Publisher Full Text

114. Meng MB, Zaorsky NG, Deng L, et al.: Pericytes: a double-edged sword in cancer therapy. Future Oncol. 2015; 11(1): 169-79. PubMed Abstract | Publisher Full Text

115. Tolaney SM, Boucher Y, Duda DG, et al:: Role of vascular density and normalization in response to neoadjuvant bevacizumab and chemotherapy in breast cancer patients. Proc Natl Acad Sci U S A. 2015; 112(46): 14325-30. PublMed Abstract | Publisher Full Text | Free Full Text

116. Volz NB, Stintzing S, Zhang W, et al.: Genes involved in pericyte-driven tumor maturation predict treatment benefit of first-line FOLFIRI plus bevacizumab in patients with metastatic colorectal cancer. Pharmacogenomics J. 2015; 15(1): $69-76$.

PubMed Abstract | Publisher Full Text

117. Kim J, de Sampaio PC, Lundy DM, et al:: Heterogeneous perivascular cell coverage affects breast cancer metastasis and response to chemotherapy. $\mathrm{JCl}$ Insight. 2016; 1(21): e90733.

PubMed Abstract | Publisher Full Text | Free Full Text

118. Moccia F, Zuccolo E, Poletto V, et al.: Endothelial progenitor cells support tumour growth and metastatisation: implications for the resistance to antiangiogenic therapy. Tumour Biol. 2015; 36(9): 6603-14. PubMed Abstract | Publisher Full Text

119. F Odent Grigorescu G, Rosca AM, Preda MB, et al: Synergic effects of VEGF-A and SDF-1 on the angiogenic properties of endothelial progenitor cells. J Tissue Eng Regen Med. 2017; 11(11): 3241-3252. PubMed Abstract | Publisher Full Text | F1000 Recommendation

120. Kalathil SG, Lugade AA, lyer R, et al:: Endothelial progenitor cell number and ERK phosphorylation serve as predictive and prognostic biomarkers in advanced hepatocellular carcinoma patients treated with sorafenib. Oncoimmunology. 2016; 5(10): e1226718 PubMed Abstract | Publisher Full Text | Free Full Text

121. Safarzadeh E, Orangi M, Mohammadi H, et al:: Myeloid-derived Suppresso Cells: important contributors to tumor progression and metastasis. $J$ Cell Physiol. 2018; 233(4): 3024-3036. PubMed Abstract | Publisher Full Text

122. Kumar V, Patel S, Tcyganov E, et al.: The Nature of Myeloid-Derived Suppressor Cells in the Tumor Microenvironment. Trends Immunol. 2016; 37(3): 208-220. PubMed Abstract | Publisher Full Text | Free Full Text

123. Shojaei F, Wu X, Qu X, et al.: G-CSF-initiated myeloid cell mobilization and angiogenesis mediate tumor refractoriness to anti-VEGF therapy in mouse models. Proc Natl Acad Sci U S A. 2009; 106(16): 6742-7. PubMed Abstract | Publisher Full Text | Free Full Text

124. F Shojaei $F$, Wu X, Malik AK, et al.: Tumor refractoriness to anti-VEGF treatment is mediated by $\mathrm{CD}_{11} \mathrm{~b}^{+} \mathrm{Gr}^{1+}$ myeloid cells. Nat Biotechnol. 2007; 25(8): 911-20.

PubMed Abstract | Publisher Full Text | F1000 Recommendation 
125. Du Four S, Maenhout SK, De Pierre K, et al:: Axitinib increases the infiltration of immune cells and reduces the suppressive capacity of monocytic MDSCs in an intracranial mouse melanoma model. Oncoimmunology. 2015; 4(4): e998107. PubMed Abstract | Publisher Full Text | Free Full Text

126. Finke $\mathrm{J}$, Ko J, Rini B, et al:: MDSC as a mechanism of tumor escape from sunitinib mediated anti-angiogenic therapy. Int Immunopharmacol. 2011; 11(7): 856-61.

PubMed Abstract | Publisher Full Text | Free Full Text

127. Rivera LB, Meyronet D, Hervieu V, et al:: Intratumoral myeloid cells regulate responsiveness and resistance to antiangiogenic therapy. Cell Rep. 2015; 11(4): 577-91.

PubMed Abstract | Publisher Full Text | Free Full Text

128. F Labelle M, Begum S, Hynes RO: Direct signaling between platelets and cancer cells induces an epithelial-mesenchymal-like transition and promotes metastasis. Cancer Cell. 2011; 20(5): 576-90.

PubMed Abstract | Publisher Full Text | Free Full Text | F1000 Recommendation

129. Peterson JE, Zurakowski D, Italiano JE Jr, et al.: VEGF, PF4 and PDGF are elevated in platelets of colorectal cancer patients. Angiogenesis. 2012; 15(2): 265-73. PubMed Abstract | Publisher Full Text

130. Walsh TG, Metharom P, Berndt MC: The functional role of platelets in the regulation of angiogenesis. Platelets. 2015; 26(3): 199-211. PubMed Abstract | Publisher Full Text

131. Cao Y: Multifarious functions of PDGFs and PDGFRs in tumor growth and metastasis. Trends Mol Med. 2013; 19(8): 460-73. PubMed Abstract | Publisher Full Text

132. Radziwon-Balicka A, Moncada de la Rosa C, Jurasz P: Platelet-associated angiogenesis regulating factors: a pharmacological perspective. Can J Physiol Pharmacol. 2012; 90(6): 679-88. PubMed Abstract | Publisher Full Text

133. F Di Vito C, Navone SE, Marfia G, et al.: Platelets from glioblastoma patients promote angiogenesis of tumor endothelial cells and exhibit increased VEGF content and release. Platelets. 2017; 28(6): 585-594. PubMed Abstract | Publisher Full Text | F1000 Recommendation

134. F Crawford Y, Kasman I, Yu L, et al:: PDGF-C mediates the angiogenic and tumorigenic properties of fibroblasts associated with tumors refractory to anti-VEGF treatment. Cancer Cell. 2009; 15(1): 21-34. PubMed Abstract | Publisher Full Text | F1000 Recommendation

135. Kinugasa $Y$, Matsui T, Takakura N: CD44 expressed on cancer-associated fibroblasts is a functional molecule supporting the stemness and drug resistance of malignant cancer cells in the tumor microenvironment. Stem Cells. 2014; 32(1): 145-56. PubMed Abstract | Publisher Full Tex

136. F Thomas AA, Fisher JL, Hampton TH, et al.: Immune modulation associated with vascular endothelial growth factor (VEGF) blockade in patients with glioblastoma. Cancer Immunol Immunother. 2017; 66(3): 379-389. PubMed Abstract | Publisher Full Text | F1000 Recommendation

137. Kloepper J, Riedemann L, Amoozgar Z, et al:: Ang-2/VEGF bispecific antibody reprograms macrophages and resident microglia to anti-tumor phenotype and prolongs glioblastoma survival. Proc Natl Acad Sci U S A. 2016; 113(16): 4476-81.

PubMed Abstract | Publisher Full Text | Free Full Text

138. Cicatiello V, Apicella I, Tudisco L, et al:: Powerful anti-tumor and anti-angiogenic activity of a new anti-vascular endothelial growth factor receptor 1 peptide in colorectal cancer models. Oncotarget. 2015; 6(12): 10563-76. PubMed Abstract | Publisher Full Text | Free Full Text

139. Smirnov IV, Gryazeva IV, Samoilovich MP, et al.: [Endoglin (CD105)--a target for visualization and anti-angiogenic therapy for malignant tumors]. Vopr Onkol. 2015; 61(6): 898-907. PubMed Abstract

140. Li J, Zhang Z, Lv L, et al.: A bispecific antibody (ScBsAbAgn-2/TSPO) target for Ang-2 and TSPO resulted in therapeutic effects against glioblastomas. Biochem Biophys Res Commun. 2016; 472(2): 384-91. PubMed Abstract | Publisher Full Tex

141. Li JL, Sainson RC, Oon CE, et al:: DLL4-Notch signaling mediates tumor resistance to anti-VEGF therapy in vivo. Cancer Res. 2011; 71(18): 6073-83. PubMed Abstract | Publisher Full Text

142. Huang J, Hu W, Hu L, et al:: DII4 Inhibition plus Aflibercept Markedly Reduces Ovarian Tumor Growth. Mol Cancer Ther. 2016; 15(6): 1344-52. PubMed Abstract | Publisher Full Text

143. Chiorean EG, LoRusso P, Strother RM, et al: A Phase I First-in-Human Study of Enoticumab (REGN421), a Fully Human Delta-like Ligand 4 (DII4) Monoclonal Antibody in Patients with Advanced Solid Tumors. Clin Cancer Res. 2015; 21(12): 2695-703. PubMed Abstract | Publisher Full Text

144. Smith DC, Eisenberg PD, Manikhas G, et al: A phase I dose escalation and expansion study of the anticancer stem cell agent demcizumab (anti-DLL4) in patients with previously treated solid tumors. Clin Cancer Res. 2014; 20(24): 6295-303.

PubMed Abstract | Publisher Full Text
145. Bach DH, Kim SH, Hong JY, et al.: Salternamide A Suppresses Hypoxia-Induced Accumulation of HIF-1 $\alpha$ and Induces Apoptosis in Human Colorectal Cancer Cells. Mar Drugs. 2015; 13(11): 6962-76. PubMed Abstract | Publisher Full Text | Free Full Text

146. Falchook GS, Wheler JJ, Naing A, et al:: Targeting hypoxia-inducible factor$1 \alpha$ (HIF-1 $\alpha$ ) in combination with antiangiogenic therapy: a phase I trial of bortezomib plus bevacizumab. Oncotarget. 2014; 5(21): 10280-92. PubMed Abstract | Publisher Full Text | Free Full Text

147. Jeong W, Park SR, Rapisarda A, et al.: Weekly EZN-2208 (PEGylated SN-38) in combination with bevacizumab in patients with refractory solid tumors. Invest New Drugs. 2014; 32(2): 340-6.

PubMed Abstract | Publisher Full Text

148. Di Desidero T, Xu P, Man ST, et al.: Potent efficacy of metronomic topotecan and pazopanib combination therapy in preclinical models of primary or late stage metastatic triple-negative breast cancer. Oncotarget. 2015; 6(40): $42396-410$. PubMed Abstract | Publisher Full Text | Free Full Text

149. Yin T, He S, Shen G, et al.: HIF-1 Dimerization Inhibitor Acriflavine Enhances Antitumor Activity of Sunitinib in Breast Cancer Model. Oncol Res. 2014; 22(3): $139-45$. PubMed Abstract | Publisher Full Tex

150. F Postow MA, Chesney J, Pavlick AC, et al.: Nivolumab and ipilimumab versus ipilimumab in untreated melanoma. N Engl J Med. 2015; 372(21): 2006-17. PubMed Abstract | Publisher Full Text | Free Full Text | F1000 Recommendation

151. F Robert C, Schachter J, Long GV, et al.: Pembrolizumab versus Ipilimumab in Advanced Melanoma. N Engl J Med. 2015; 372(26): 2521-32. PubMed Abstract | Publisher Full Text | F1000 Recommendation

152. $\mathrm{F}$ Schmittnaegel $\mathrm{M}$, Rigamonti $\mathrm{N}$, Kadioglu $\mathrm{E}$, et al.: Dual angiopoietin-2 and VEGFA inhibition elicits antitumor immunity that is enhanced by PD-1 checkpoint blockade. Sci Transl Med. 2017; 9(385): pii: eaak9670. PublMed Abstract | Publisher Full Text | F1000 Recommendation

153. F Allen E, Jabouille A, Rivera LB, et al:: Combined antiangiogenic and anti-PDL1 therapy stimulates tumor immunity through HEV formation. Sci Transl Med. 2017; 9(385): pii: eaak9679.

PubMed Abstract | Publisher Full Text | Free Full Text | F1000 Recommendation

154. Hughes PE, Caenepeel S, Wu LC: Targeted Therapy and Checkpoin Immunotherapy Combinations for the Treatment of Cancer. Trends Immunol. 2016; 37(7): 462-76. PubMed Abstract | Publisher Full Tex

155. F Nguyen L, Fifis T, Christophi C: Vascular disruptive agent OXi4503 and antiangiogenic agent Sunitinib combination treatment prolong survival of mice with CRC liver metastasis. BMC Cancer. 2016; 16: 533 PubMed Abstract | Publisher Full Text | Free Full Text | F1000 Recommendation

156. Gerstner ER, Ye X, Duda DG, et al:: A phase I study of cediranib in combination with cilengitide in patients with recurrent glioblastoma. Neuro Oncol. 2015; 17(10): 1386-92.

PubMed Abstract | Publisher Full Text | Free Full Text

157. Reynolds AR, Hart IR, Watson AR, et al.: Stimulation of tumor growth and angiogenesis by low concentrations of RGD-mimetic integrin inhibitors. Nat Med. 2009; 15(4): 392-400. PubMed Abstract | Publisher Full Tex

158. F Caswell PT, Chan M, Lindsay AJ, et al.: Rab-coupling protein coordinates recycling of alpha5beta1 integrin and EGFR1 to promote cell migration in 3D microenvironments. J Cell Biol. 2008; 183(1): 143-55.

PubMed Abstract | Publisher Full Text | Free Full Text | F1000 Recommendation

159. Nakazawa $Y$, Kawano S, Matsui J, et al:: Multitargeting strategy using lenvatinib and golvatinib: maximizing anti-angiogenesis activity in a preclinical cancer model. Cancer Sci. 2015; 106(2): 201-7.

PubMed Abstract | Publisher Full Text | Free Full Text

160. Manzat Saplacan RM, Balacescu L, Gherman C, et al.: The Role of PDGFs and PDGFRs in Colorectal Cancer. Mediators Inflamm. 2017; 2017: 4708076. PubMed Abstract | Publisher Full Text | Free Full Text

161. F Cooke VG, LeBleu VS, Keskin D, et al:: Pericyte depletion results in hypoxiaassociated epithelial-to-mesenchymal transition and metastasis mediated by met signaling pathway. Cancer Cell. 2012; 21(1): 66-81. PubMed Abstract | Publisher Full Text | Free Full Text | F1000 Recommendation

162. Keskin D, Kim J, Cooke VG, et al:: Targeting vascular pericytes in hypoxic tumors increases lung metastasis via angiopoietin-2. Cell Rep. 2015; 10(7): 1066-81.

PubMed Abstract | Publisher Full Text | Free Full Text

163. Chung SW, Bae SM, Lee M, et al.: LHT7, a chemically modified heparin, inhibits multiple stages of angiogenesis by blocking VEGF, FGF2 and PDGF-B signaling pathways. Biomaterials. 2015; 37: 271-8. PubMed Abstract | Publisher Full Text

164. Kim JY, Chung SW, Kim SY, et al.: Enhanced Anti-Angiogenic Effect of Low Molecular Weight Heparin-Bile Acid Conjugates by Co-Administration of a Selective COX-2 Inhibitor. Pharm Res. 2015; 32(7): 2318-27. PubMed Abstract | Publisher Full Text 
165. F Guffanti F, Chilà R, Bello E, et al: In Vitro and In Vivo Activity of Lucitanib in FGFR1/2 Amplified or Mutated Cancer Models. Neoplasia. 2017; 19(1): 35-42. PubMed Abstract | Publisher Full Text | Free Full Text | F1000 Recommendation

166. Kienast $\mathrm{Y}$, Klein $\mathrm{C}$, Scheuer $\mathrm{W}$, et al.: Ang-2-VEGF-A CrossMab, a novel bispecific human IgG1 antibody blocking VEGF-A and Ang-2 functions simultaneously, mediates potent antitumor, antiangiogenic, and antimetastatic efficacy. Clin Cancer Res. 2013; 19(24): 6730-40. efficacy. Clin Cancer Res. 2013; 19(24):
PubMed Abstract | Publisher Full Text

167. Koh YJ, Kim HZ, Hwang SI, et al:: Double antiangiogenic protein, DAAP, targeting VEGF-A and angiopoietins in tumor angiogenesis, metastasis, and vascular leakage. Cancer Cell. 2010; 18(2): 171-84. PubMed Abstract | Publisher Full Text

168. Ruan J, Luo M, Wang C, et al.: Imatinib disrupts lymphoma angiogenesis by targeting vascular pericytes. Blood. 2013; 121(26): 5192-202. PubMed Abstract | Publisher Full Text | Free Full Text

169. Liontos M, Lykka M, Dimopoulos MA, et al.: Profile of trebananib (AMG386) and its potential in the treatment of ovarian cancer. Onco Targets Ther. 2014; 7 : 1837-45

PubMed Abstract | Publisher Full Text | Free Full Text

170. Johnson PJ, Qin S, Park JW, et al.: Brivanib versus sorafenib as first-line therapy in patients with unresectable, advanced hepatocellular carcinoma: results from the randomized phase III BRISK-FL study. J Clin Oncol. 2013; 31(28): 3517-24.

PubMed Abstract | Publisher Full Text

171. Llovet JM, Decaens T, Raoul JL, et al:: Brivanib in patients with advanced hepatocellular carcinoma who were intolerant to sorafenib or for whom sorafenib failed: results from the randomized phase III BRISK-PS study. J Clin Oncol. 2013; 31(28): 3509-16.

PubMed Abstract | Publisher Full Text

172. Gao DY, Lin TsT, Sung YC, et al:: CXCR4-targeted lipid-coated PLGA nanoparticles deliver sorafenib and overcome acquired drug resistance in liver cancer. Biomaterials. 2015; 67: 194-203.

PubMed Abstract | Publisher Full Text 


\section{Open Peer Review}

\section{Current Peer Review Status:}

\section{Editorial Note on the Review Process}

Faculty Reviews are review articles written by the prestigious Members of Faculty Opinions. The articles are commissioned and peer reviewed before publication to ensure that the final, published version is comprehensive and accessible. The reviewers who approved the final version are listed with their names and affiliations.

\section{The reviewers who approved this article are:}

\section{Version 1}

\section{Andrew Reynolds}

Tumour Biology Team, The Breast Cancer Now Toby Robins Research Centre, The Institute of Cancer Research, London, UK

Competing Interests: No competing interests were disclosed.

\section{Miguel Quintela-Fandino}

Breast Cancer Clinical Research Unit, CNIO-Spanish National Research Cancer Centre, Madrid, Spain

Competing Interests: No competing interests were disclosed.

The benefits of publishing with F1000Research:

- Your article is published within days, with no editorial bias

- You can publish traditional articles, null/negative results, case reports, data notes and more

- The peer review process is transparent and collaborative

- Your article is indexed in PubMed after passing peer review

- Dedicated customer support at every stage

For pre-submission enquiries, contact research@f1000.com 